\begin{tabular}{|c|c|c|}
\hline Beitr. Ent. & Keltern & ISSN 0005-805X \\
\hline $\mathbf{5 7}(2007) 2$ & S. $367-396$ & 21.12 .2007 \\
\hline
\end{tabular}

\title{
A revision of the species of Pronomaea ERICHSON of the Western Palaearctic region, including Middle Asia
}

\section{(Coleoptera: Staphylinidae: Aleocharinae: Pronomaeini)}

With 51 figures, 5 maps and 1 table

\section{VOLKer Assing}

\begin{abstract}
Summary
Based on an examination of types and additional material, 12 species of Pronomaea Erichson, 1837 are recognised in the Western Palaearctic region, including Middle Asia. Distinguishing characters are described and illustrated. Five species are new to science: P. corsicana sp. n. (France: Corsica), P. sardoa sp. n. (Italy: Sardinia), P. sicula sp. n. (Italy: Sicily), P. wunderlei sp. n. (Greece: Crete), and P. spalacis sp. n. (Israel). The following synonymies are established: P. araxicola Reitter, $1898=P$. libanotica Fagel, 1969, syn. $\mathbf{n}$., $=P$. orientalis FAgel, 1969, syn. n.; P. picea Heer, $1841=$ P. dalmatina SAChSE, 1852, syn. $\mathbf{n} .,=P$. korgei Lohse, 1974, syn. n. A neotype is designated for $P$. picea HeER; lectotypes are designated for $P$. araxicola Reitter, $P$. dalmatina Sachse, $P$. rostrata Erichson, and $P$. korgei Lohse. A key to species and a synonymic catalogue of the 15 Pronomaea species presently known from the Palaearctic region are provided. The distributions of all the Western Palaearctic species are mapped.
\end{abstract}

\section{Key words}

Coleoptera, Staphylinidae, Pronomaeini, Pronomaea, Western Palaearctic region, taxonomy, new species, new synonymies, neotype designation, lectotype designations, key to species, synonymic catalogue, zoogeography, distributions.

New species

Pronomaea corsicana sp. n., P. sardoa sp. n., P. sicula sp. n., P. spalacis sp. n., P. wunderlei sp. n.

\section{Zusammenfassung}

Nach Revision von Typen und weiterem Material umfasst die Gattung Pronomaea Erichson, 1837 in der Westpaläarktis einschließlich Mittelasien 12 Arten. Differentialmerkmale werden beschrieben und abgebildet. Fünf Arten sind neu für die Wissenschaft: P. corsicana sp. n. (Frankreich: Korsika), P. sardoa sp. n. (Italien: Sardinien), P. sicula sp. n. (Italien: Sizilien), P. wunderlei sp. n. (Griechenland: Kreta) und P. spalacis sp. n. (Israel). Vier Namen werden neu synonymisiert: P. araxicola ReItTer, $1898=$ P. libanotica Fagel, 1969, syn. n., = P. orientalis Fagel, 1969, syn. n.; P. picea Heer, 1841 = P. dalmatina SAChSe, 1852, syn. n., = P. korgei LoHSE, 1974, syn. n. Für P. picea Heer wird ein Neotypus, für $P$. araxicola ReItTer, $P$. dalmatina SAChSe, P. rostrata Erichson und P. korgei LohSE werden Lectotypen designiert. Für die Arten der Westpaläarktis wird eine Bestimmungstabelle erstellt. Die 15 derzeit aus der Paläarktis bekannten Pronomaea-Arten und ihre Synonyme werden in einem Katalog zusammen gestellt. Die Verbreitung der westpaläarktischen Arten wird anhand von Karten illustriert. 


\section{Introduction and taxonomic history}

The genus Pronomaea was described by Erichson (1837) to include P. rostrata Erichson, 1837, the type species by monotypy. Only few years later, Heer (1841) published the description of a second Pronomaea species, P. picea, from the surroundings of Genf, Switzerland, and SACHSE (1856) added $P$. dalmatina from Dalmatia. It was more than four decades until the next Palaearctic species was described, P. araxicola from the Caucasus region (Reitter 1898). Bernhauer \& Scheerpeltz (1926) list 15 valid Pronomaea species, two from the Palaearctic region, P. rostrata (with P. picea and P. dalmatina as junior synonyms) and P. araxicola, eight from the Ethiopian, four from the Oriental region, and one from the Central America. In the Palaearctic region, the taxonomy of the genus remained largely unchanged until IabloкоғF-Khnzorian (1957) and LOHSE (1968) described $P$. subterranea and $P$. horioni from Armenia and northern Italy, respectively. FAGel (1969) treated Pronomaea again, confirming the separation of P. rostrata and P. horioni, providing additional localities, and describing three new species from the eastern Mediterranean. LoHSE (1974) synonymised $P$. horioni with $P$. rostrata and made the name $P$. korgei available for his previous interpretation of $P$. rostrata. Additional species from the Palaearctic region were reported by PACE $(1989,1998)$, who described $P$. nepalensis from Nepal and recorded $P$. thaxteri Bernhauer, 1915 from China. In a revision of the Caucasian and Middle Asian species of the genus, Semenov (2003) synonymised $P$. subterranea with $P$. araxicola and described two species, $P$. khnzoriani from Armenia and $P$. flavirostris from Tajikistan. These developments are summarised in the catalogue of Palaearctic Coleoptera by SMETANA (2004), who lists ten valid species with four synonyms from the Palaearctic region, eight from the Western Palaearctic, including Middle Asia, and two from the Eastern Palaearctic. Only recently, two additional Palaearctic species were described, P. taiwanensis from Taiwan (PACE 2007) and P. procerula from Iran (Assing in press).

Based on the evidence available today, Pronomaea is likely to have a Palaearctic distribution, with one species occurring in both the Palaearctic and the Oriental regions. The genus is unknown from the Nearctic region (Newton et al. 2001), and the species originally described from the Afrotropical and the Oriental regions apparently refer to other genera, e. g. Nopromaea Cameron, 1930 (P. africana Eppelsheim, 1895, P. fortepunctata Eichelbaum, 1913) (Pace 1994) and Neosilusa Cameron, 1920 (P. subrufa Motschulsky, 1861) (Smetana 2004). This at least applies to those species that have been subject to recent revision. Pronomaea leontopolitana Cameron, 1919 was synonymised with $P$. thaxteri by CAMERON (1936).

The present study was inspired mainly by a study of Pronomaea material from the eastern Mediterranean, suggesting the presence of undescribed species, as well as some synonymies. In particular, it seemed somewhat unlikely that, in view of the relative abundances of the two species occurring in Central Europe, P. korgei LoHse should not have a senior synonym. Finally, based on preliminary data, the current concepts of the distributions of the Western Palaearctic Pronomaea species appeared to be highly doubtful, a suspicion to be confirmed by the subsequent study of the material from various major collections.

\section{Material and methods}

The material referred to in this study is deposited in the following public and private collections: 


$\begin{array}{ll}\text { BMNH } & \text { The Natural History Museum, London (R. G. Booth) } \\ \text { DEI } & \text { Deutsches Entomologisches Institut, Müncheberg (L. Zerche, L. Behne) } \\ \text { FMNH } & \text { Field Museum of Natural History, Chicago (J. Boone, A. Newton) } \\ \text { IRSNB } & \text { Institut royal des Sciences naturelles de Belgique, Bruxelles (Y. Gérard) } \\ \text { MHNG } & \text { Muséum d'histoire naturelles Genève (G. Cuccodoro) } \\ \text { MNHUB } & \text { Museum für Naturkunde der Humboldt-Universiät Berlin (J. Frisch, J. Willers) } \\ \text { NHMW } & \text { Naturhistorisches Museum Wien (H. Schillhammer) } \\ \text { SMNS } & \text { Staatliches Museum für Naturkunde Stuttgart (W. Schawaller) } \\ \text { cAss } & \text { author's private collection } \\ \text { cFel } & \text { private collection Benedikt Feldmann, Münster } \\ \text { cKöh } & \text { private collection Frank Köhler, Bornheim } \\ \text { cRen } & \text { private collection Klaus Renner, Bielefeld } \\ \text { cSch } & \text { private collection Michael Schülke, Berlin } \\ \text { cTro } & \text { private collection Marc Tronquet, Molitg-les-Bains } \\ \text { cVog } & \text { private collection Jürgen Vogel, Görlitz } \\ \text { cWun } & \text { private collection Paul Wunderle, Mönchengladbach } \\ \text { cZan } & \text { private collection Adriano Zanetti, Verona }\end{array}$

The morphological studies were conducted using a Stemi SV 11 microscope (Zeiss Germany) and a Jenalab compound microscope (Carl Zeiss Jena) with a drawing tube. For the photographs a digital camera (Nikon Coolpix 995) was used.

The length of the elytra was measured along the suture from the apex of the scutellum to the posterior elytral margin, that of the median lobe of the aedeagus from the apex of the ventral process to the base.

The maps were generated using the online generic mapping tool (GMT) of the Geomar website at www. aquarius.ifm-geomar.de/omc.

\section{The Pronomaea species of the Western Palaearctic and Middle Asia}

\section{Pronomaea rostrata ERICHSON, 1837 (Figs 1-8, Map 1)}

Pronomaea rostrata ERICHSON, 1837: $379 \mathrm{f}$.

Pronomaea horioni LoHSE, 1968: 41 f.; synonymy by LoHSE (1974).

\section{Type material examined:}

Lectotype 우 , here designated: "ㅇ / Berolin / 5652 / rostrata Er. Berol. / Pronomaea rostrata Er., Lectotypus, det. Dr. G. A. Lohse / Pronomaea rostrata det. J. Vogel 2000 / Lectotypus o Pronomaea rostrata Erichson desig. V. Assing 2007 / Pronomaea rostrata Erichson, det. V. Assing 2007" (MNHUB). Paralectotypes: 3 우 우: "우 / Berolin, Nr. 5652 / Pronomaea rostrata det. J. Vogel 2000" (MNHUB); 1 잉ㅇㅇ / Austr. / Nr. 5652" (MNHUB); 1 이 " ㅇ / Austria / Nr. 5652" (MNHUB).

\section{Comments:}

The original description of $P$. rostrata is based on an unspecified, but apparently low number ("ein seltener Käfer") of syntypes (ERICHSON 1837). A type locality is not specified. Six syntypes, all of them females and four of them from Berlin, were found in the collections at the MNHUB. A specimen from "Berolin" is here designated as the lectotype. 

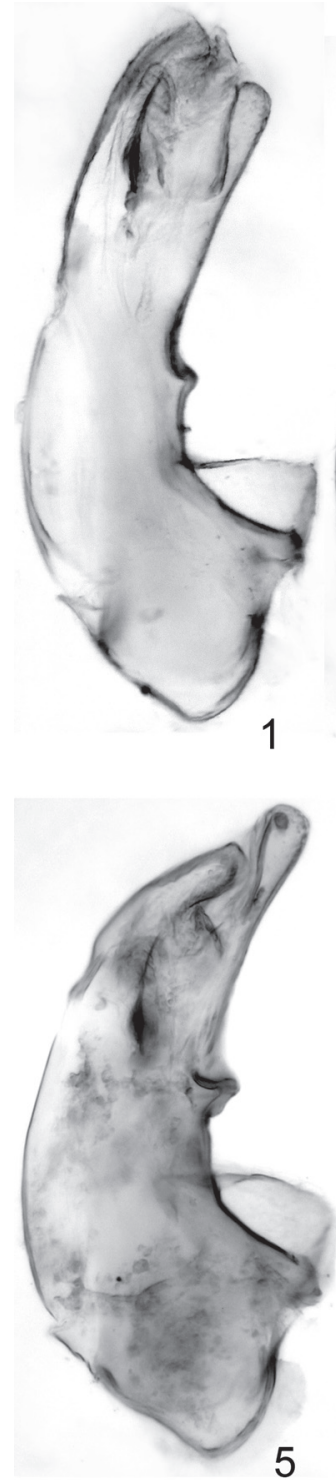

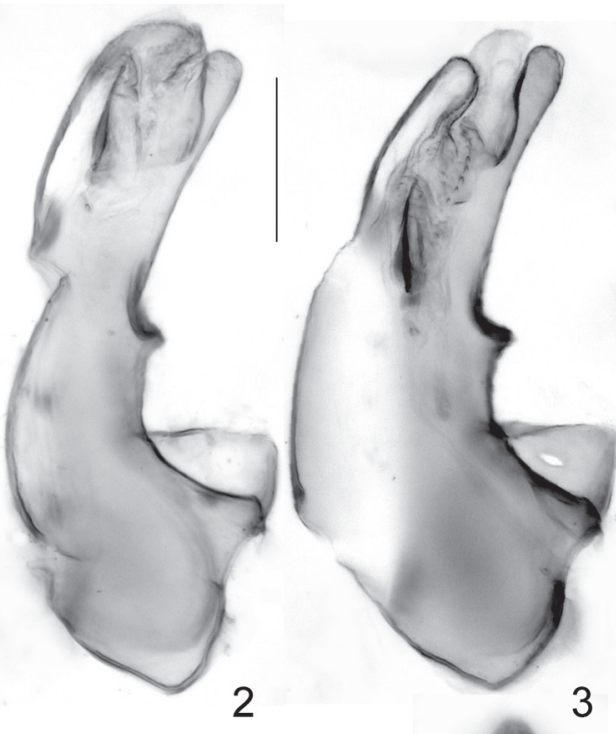

3

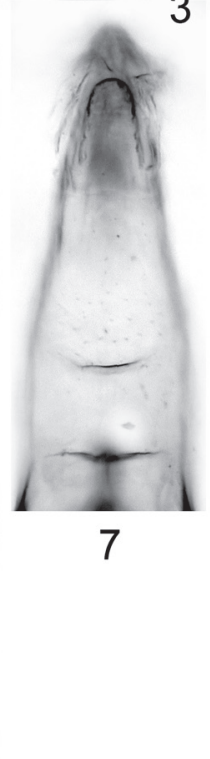

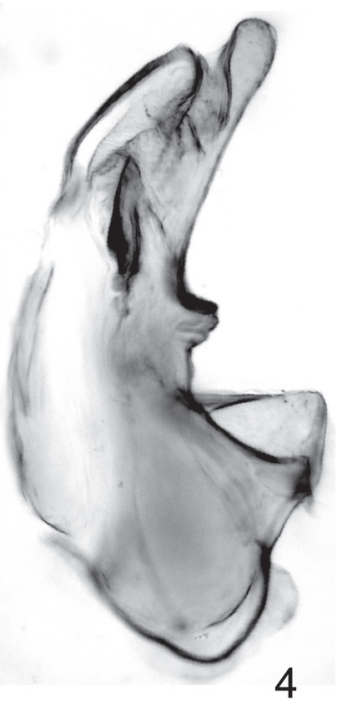

4

Figs 1-8: Pronomaea rostrata Erichson: median lobe of aedeagus in lateral view (1-6) of males from Germany (1), southern Spain (2), Ukraine (3), Poland (4), Corsica (5), and Tunisia (6); apical part of median lobe of aedeagus in ventral view (7); spermatheca (8). Scale bars: $0.1 \mathrm{~mm}$.

Without examination of the type material of $P$. rostrata and P. picea, LoHse (1968) described Pronomaea horioni based on a female holotype and a male paratype from "Leifers, Prov. Bozen, Norditalien", as well as a female "paratypoid" [sic] from "Avisio-Adge (Trentino)". He distinguished the new species from $P$. rostrata and provided simple sketches of the genitalia of the two species. He inferred from the details in the original description of P. picea Heen (smaller size, paler coloration especially of the basal antennomeres) that $P$. horioni was unlikely to be conspecific with the type material of that name. Inspired by this paper, FAGEL (1969) studied the 
material of the IRSNB and his own collection and listed numerous additional localities for both P. rostrata sensu LoHSE (1968) and P. horioni. However, only some years later Lohse was informed by H. Korge (Berlin), who had studied the type material of $P$. rostrata at the MNHUB, that his description of $P$. horioni in fact referred to $P$. rostrata. In his key to Central European Pronomaea, LoHse (1974) then synonymised $P$. horion $i$ with $P$. rostrata and introduced the name $P$. korgei - as a replacement name ("n. n.") [sic] - for his previous interpretation of P. rostrata. Remarkably, he made no reference to $P$. picea, although the paler basal antennomeres, which he had previously emphasised to distinguish $P$. picea from $P$. horioni, are one of the external characters given in the key to separate $P$. korgei from $P$. rostrata.

The types of $P$. horioni are apparently not deposited in the MHNG and were not studied, but the morphological details and figures in the original description leave no doubt that the synonymy with $P$. rostrata is correct.

Additional material examined: Tunisia: 2 exs., Aïn Draham, leg. Normand (MHNG, cAss).

Gibraltar: 1 ex., "Gibraltar", leg. Walker (cAss).

Spain: Castilla-León: 1 ex., Caboalles, leg. Paganetti (DEI). Castilla-La Mancha: 1 ex., Cuenca, Tragacete, leg. Champion (BMNH). Andalucía: 1 ex., Sierra Nevada, above Capileira, 1900 m, 23.III.1994, leg. Assing (cAss); 2 exs., Sierra de Cazorla, 6.X.1993, leg. Wunderle (cWun, cAss).

France: Languedoc-Roussillon: 1 ex., Pyrénées-Orientales, Les Bains de la Preste, leg. Perrot (MHNG).

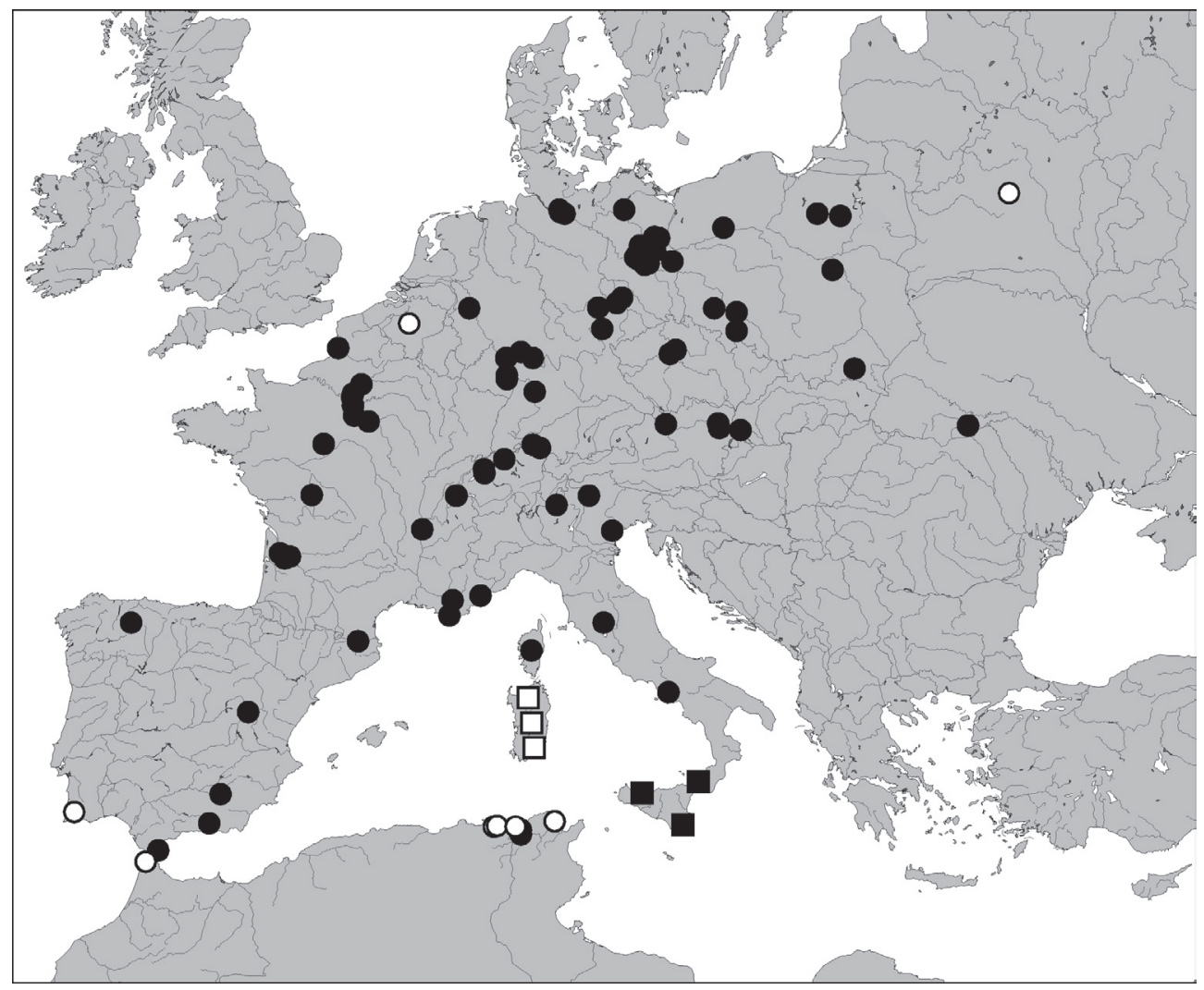

Map 1: Distributions of Pronomaea rostrata ERICHSON (filled circles: examined records; open circles: selected plausible literature records by Fagel (1969) and Fauvel (1902)), P. sardoa sp. n. (open squares), and $P$. sicula sp. n. (filled squares). 
Aquitaine: 1 ex., Gironde, Mérignac, Eyquems, leg. de Borre (MHNG); 6 exs., Gironde, Cambes, 27.II.1938, leg. Giraud (MHNG, cAss); 1 ex., same data, but 28.IX.1941 (cAss); 4 exs., same data, but 11.III.1939 (MHNG); 1 ex., Gironde, Daignac, 26.V.1929, leg. Tempère (MHNG); 1 ex., Madirac, 21.VIII.1938, leg. Giraud (MHNG); 1 ex., Bordeaux, Garonne inundation (MHNG). Picardie: 3 exs., Oise, Cinqueux, VIII.1912, leg. Méquignon (MHNG, cAss); 1 ex., Le Crotoy, II.1891 (cAss). Poitou-Charentes: 3 exs. Vienne, Morthemer, leg. Mesmin (BMNH, MHNG). Île-de-France: 1 ex., Seine-et-Martne, Moretsur-Loing, inundation, I.1924, leg. Royer (MHNG); 1 ex., Herblay, IV.1891 (BMNH); 2 exs., Chaville, IX.1901 (BMNH); 1 ex., Valmondois, IX.1891 (BMNH); 1 ex., Lardy, VII.1903 (BMNH). Centre: 1 ex., Loire-et-Cher, Vendôme, S La Rippe, 30.IV.1960 (MHNG). Rhône-Alpes: 1 ex., Vienne, Les Bourielles, 18.III.1887, leg. Mesmin (NHMW). Provence: 1 ex., Var, Toulon, 3.IV.1947, leg. Barbier (MHNG); 1 ex., Pontevès, in moss near stream, 31.VIII.1955, leg. Bureau (SMNS); 1 ex., Alpes-Maritimes, Loup inundation, XI.1957 (cAss). Corse: 3 exs., locality not specified, leg. Revelière (NHMW, cAss). Locality not specified: 4 exs. (BMNH).

Switzerland: 1 ex., Vaud, Jura, Givrins, IX.1964, leg. Toumayeff (MHNG); 1 ex., Vaud, forest above Trélex (MHNG); 1 ex., Bern, Aarberg, 7.VIII. (MHNG); 1 ex., Bern, Bienne, 7.VI. (MHNG); 1 ex., Aargau ["Argovie"], Jura (MHNG); 1 ex., locality not specified (MHNG).

Germany: Nordrhein-Westfalen: 1 ex., Neuss (DEI). Hessen: 1 ex., Frankfurt, leg. Heyden (DEI); 7 exs., locality not specified ["Hassia"], leg. Scriba (DEI). Rheinland-Pfalz: 1 ex., Heidesheim, park (cAss); 1 ex., Bad Dürkheim (NHMW); 3 exs., Grünstadt, leg. Eppelsheim (DEI). Baden-Württemberg: 2 exs., Heilbronn (NHMW, cAss); 1 ex., Bodensee, Überlingen, VII.1957, leg. Folwaczny (SMNS); 1 ex., Bodensee, 9.VII.1952, leg. Vogt (BMNH). Bayern: 1 ex., Aschaffenburg, leg. Singer (FMNH). Hamburg: 2 exs., Bergedorf, 31.III.1893 (DEI); 2 exs., Boberg, 2.VII.1881 (DEI); 1 ex., Geesthacht, 6.X.1867 (DEI); 2 exs., Geesthacht, 17.V.1880 (DEI). Mecklenburg-Vorpommern: 1 ex., Waren, IX.1031, leg. Hainmüller (cVog). Brandenburg/Berlin: 2 exs., Borgsdorf, leg. Neresheimer (DEI); 1 ex., Oderberg, leg. Neresheimer (DEI); 1 ex., Berlin env., Klein Machnow, leg. Neresheimer (DEI); 1 ex., Berlin, Grunewald (DEI); 2 exs., Röntgental, leg. Neresheimer (DEI); 1 ex., Mellensee, Königswusterhausen, leg. Neresheimer (DEI); 1 ex., Königswusterhausen, leg. Neresheimer (DEI); 1 ex., Mittenwalde env., leg. Neresheimer (DEI); 2 exs., Strausberg env., leg. Neresheimer (DEI); 4 exs., Stahnsdorf, leg. Neresheimer (DEI, cAss); 1 ex., Hönow env., leg. Neresheimer (DEI); 3 exs., Chorin, leg. Neresheimer (DEI); 1 ex., Berlin, Wannsee (DEI); 1 ex., Kladow am Wannsee, leg. Wagner (cAss); 3 exs., Berlin (DEI); 2 exs., Frankfurt/Oder, 8.VIII.1933, leg. Schukatschek (MHNG, cAss). Sachsen-Anhalt: 2 exs., Laucha (Unstrut) $\left[51^{\circ} 13^{\prime} \mathrm{N}, 11^{\circ} 40^{\prime} \mathrm{E}\right]$ (DEI). Thüringen: 3 exs., locality not specified (NHMW). Sachsen: 1 ex., Eilenburg, 15.II.1953, leg. Linke (cAss); 3 exs., Leipzig ["Lipsia"], Ranzau (DEI); 1 ex., locality not specified, leg. Märkel (cVog). Locality not specified: 1 ex., "Germ. bor." (NHMW); 7 exs., "Germany" (BMNH).

Austria: Oberösterreich: 1 ex., Linz (NHMW). Niederösterreich: 1 ex., Kritzendorf, Donauauen (NHMW); 1 ex., locality not specified, leg. Zoufal (MHNG). Wien: 1 ex., Wien env., leg. Breit (NHMW).

Italy: Lombardia: 1 ex., Teglio (SO), 800 m, 15.V.1973, leg. Dioli (cZan). Veneto: 1 ex., Venezia, N Lisbinolo [?] [date illegible], leg. Gridelli (cAss). Toscana: 2 exs., Mte. Cetona, leg. Bargagli (NHMW, cAss).

Poland: 4 exs., Podkowa Leśna, 12.VII.1934, leg. Tenenbaum (FMNH, cAss); 1 ex., Wrocław, 1.VI.1901 (cVog); 1 ex., Wrocław, 21.VI.1905 (cVog); 1 ex., Legnica, 16.V.1908 (cVog); 1 ex., Legnica (DEI);

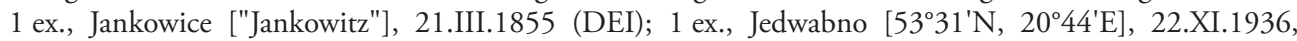
leg. Folwaczny (SMNS); 1 ex., Tarnowiec, 26.XII.1927 (SMNS); 1 ex., Henryków ["Heinrichan", recte Heinrichau; $\left.50^{\circ} 39^{\prime} \mathrm{N}, 17^{\circ} 00^{\prime} \mathrm{E}\right]$, leg. v. Bodemeyer (SMNS); 1 ex., Lomnica [5306' N, 16 $\left.31^{\circ} \mathrm{E}\right]$ ["Netzekreis, Lemnitz"], III.1940 (cVog).

Czech Republic: 2 exs., Vrané, VII.1926 (FMNH, cAss); 3 exs., Praha env., Vrané, leg. Rodt, Skalitzky (NHMW, cAss); 1 ex., Praha, garden, 1892, leg. Skalitzky (NHMW); 1 ex., Brandys n. L., 31.III.1895 leg. Skalitzky (cAss).

Slovakia: 2 exs., Bratislava, leg. Zoufal (NHMW, cAss).

Ukraine: 1 ex., Tscherniwzi ["Bukowina, Cernowitz"] (cAss).

Locality not specified or illegible: 12 exs. (BMNH, DEI). 


\section{Redescription:}

3.1-4.0 mm. Usual coloration: Body blackish brown to blackish, with the posterior part of the elytra usually slightly paler brown; legs reddish to brown; antennae dark brown to blackish brown, basal antennomeres at most only slightly paler; maxillary palpi reddish brown to blackish brown. Head with puncturation variable, coarse and distinct to shallow; interstices without microsculpture. Eyes usually slightly longer than postocular region in dorsal view, with numerous short setae. Antenna with antennomeres I-III of subequal length and distinctly oblong; IV-V usually weakly oblong; VI approximately as wide as long; VII-X of increasing width and increasingly transverse, but $\mathrm{X}$ usually less than 1.5 times as wide as long.

Pronotum relatively large in relation to head and of variable shape, 1.10-1.25 [sic] times as wide as long and about 1.3-1.4 times as wide as head; lateral margins not sinuate in posterior half; puncturation variable, ranging from moderately sparse to dense and from fine to moderately coarse, usually slightly finer and denser than that of head; interstices without microsculpture; pubescence of moderate length, usually depressed, rarely suberect, directed cephalad in anterior half and caudad in posterior half of midline; pronotal hypomera visible in lateral view.

Elytra distinctly wider than pronotum and at suture approximately as long as pronotum; posterior margin distinctly sinuate near posterior angles; puncturation rather dense and moderately fine; interstices without microsculpture. Hind wings fully developed.

Abdomen widest at base, gradually tapering posteriad; tergites III-V with pronounced anterior impressions, tergite VI without such impression; puncturation rather coarse and sparse, but density somewhat variable; interstices without microsculpture and with pronounced shine; posterior margin of tergite VII with distinct palisade fringe; tergite VIII with strongly convex posterior margin, without appreciable sexual dimorphism; sternite VIII with obtusely pointed posterior margin in both sexes.

$\sigma^{\top}$ : median lobe of aedeagus 0.39-0.44 mm long, shaped as in Figs 1-7.

i : spermatheca with relatively long duct (Fig. 8).

\section{Comparative notes:}

Owing to the pronounced intraspecific variation of the external characters of this (and other) species, as well as the similarity - and character overlap - with other Western Palaearctic congeners, a reliable separation is often possible only based on the primary sexual characters. The distribution of $P$. rostrata only overlaps with that of $P$. picea, from which it is distinguished by a completely different morphology of the aedeagus, the longer duct of the spermatheca, and often also the darker coloration of the body (especially of the antennae) and the relatively larger pronotum with generally shorter and more depressed pubescence.

\section{Distribution and bionomics:}

Based on the revised material, $P$. rostrata has an Atlanto-Mediterranean distribution, ranging from North Africa and the Iberian Peninsula to Poland and Ukraine (Map 1). There are no records from the British Isles and Scandinavia. It is apparently absent also from the extreme south of Italy, Sardinia, and the Balkans. In Italy, the southernmost confirmed record is from Toscana. In the eastern part of the distribution, the southern limit crosses Austria, Slovakia, and Ukraine. There are no confirmed records from Slovenia, Hungary, and Romania. Previous records (see e. g. CoIffait 1976; Ganglbauer 1904; Horion 1967; Luze 1904; Scheerpeltz 1937, 1964, 1965; Smetana 2004) from the following regions and countries are doubtlessly erroneous and refer to other species: Balkans (Croatia, Bosnia-Herzegovina, Yugoslavia, Bulgaria, Greece), southern Italy (including 
Sicily and Sardinia), the Caucasus region, all of the eastern Mediterranean (e. g. Turkey), Iran, Afghanistan, and Uzbekistan. The presence in Romania and Hungary seems possible, but requires verification. FAGEL (1969) reports the species (as P. horioni) from the following additional localities, all of them zoogeographically plausible: Tunisia (Fernana), Algeria (Mont Edough), Morocco (Tanger), Portugal (Caldas de Monchique), Spain (Andalucía: Lanjaron), France (Paris, Limoges, Toulouse), Belgium (Forêt de Soignes near Bruxelles), Italy (Piemonte), and Belarus (Minsk); for additional records from North Africa, which almost certainly refer to P. rostrata, see FAuvel (1902). Remarkably, the vast majority of records are very old. Specimens collected after 1950 were seen only from Spain (2 records), France (3 records), Switzerland (1 record), Germany (Baden-Württemberg: 2 records; Sachsen: 1 record; last revised record from 1957!), and Italy (1 record).

Owing to the previous confusion with other species, literature data on the ecology of the species are unreliable. The availabe evidence suggests that it is associated with moist habitats. In southern Spain it was found in wet moss at the source of a stream at an altitude of $1900 \mathrm{~m}$. One specimen from southeastern France was taken under similar conditions, but at lower altitudes. Another specimen was found in flood debris in southeastern France. Near Hamburg (Germany) the species was collected with a sweep-net on damp meadows (Horion 1967; material revised). The revised specimens were collected throughout the year with maxima in March and during the period from July through September: January (1 specimen/1 sample), February (8/3), March (11/7), April (3/3), May (5/4), June (3/3), July (11/6), August (8/5), September (6/5), October (2/2), November $(2 / 2)$, December $(1 / 1)$.

\section{Pronomaea picea HeER, 1841; revalidated (Figs 9-16, Map 2)}

Pronomaea picea HeER, 1841: 587.

Pronomaea dalmatina SACHSE, 1852: 119 f.; syn. $\mathbf{n}$.

Pronomaea korgei LOHSE, 1974: 21; syn. n.

\section{Type material examined:}

P. picea: Neotype $\sigma^{\star}$, here designated: "Bois Pourri, Blausasc AM / Coll. J. Ochs in Coll. M. Curti, MHNG 1991 / Neotypus ơ Pronomaea picea Heer, desig. V. Assing 2007 / Pronomaea picea Heer det. V. Assing 2007" (MHNG).

P. dalmatina: Lectotype ㅇ, here designated: "var. dalmatina Sachse, Dalmat. (Kahr) / Syntypus / coll. Kraatz / coll. DEI Müncheberg / Lectotypus o Pronomaea dalmatina Sachse, desig. V. Assing 2007 / Pronomaea picea Heer det. V. Assing 2007" (DEI).

P. korgei: Lectotype $\sigma^{\star}$, here designated: "11.7.73, Burgenland, Podersdorf, Hölle / korgei / Coll. G. A. Lohse MHNG - 1994 / Lectotypus ơ Pronomaea korgei Lohse, desig. V. Assing 2007 / Pronomaea picea Heer det. V. Assing 2007" (MHNG). Paralectotypes: 1 ex.: "Malcesine, Gardasee, 6.-18.V.56, Dr. G. Benick leg." (MHNG); 2 exs.: "12.3.73, Burgenland, Neusiedl, Panzergr." (MHNG).

\section{Comments:}

Pronomaea picea has been regarded as a junior synonym of $P$. rostrata by previous authors. It was described from an unspecified number of syntypes, possibly only a single specimen ("rarissima"), from "rivulis exsicatis (Genf)" (Heer 1841). According to Horn et al. (1990), the Heer collection is deposited in Zürich (ETH) and London (BMNH). However, according to the curators in charge (R. Bоотн, e-Mail 20 July, 2007; M. Schmid, e-Mail 25 July, 2007) no type material of $P$. picea was found in either collection, suggesting that it is lost. As can be inferred from the original description ("antennis basi apiceque pedibus anoque testaceis"), P. picea is distinct from 
$P$. rostrata and conspecific with the type material of $P$. dalmatina and $P$. korgei. Since $P$. picea is the senior name, it is here reinstated as a valid taxon. Although there is little doubt that the species is present in Switzerland (see Map 2), I have been unable to locate a Swiss specimen. Therefore, a male from southeastern France is here selected and designated as the neotype of P. picea.

Pronomaea dalmatina was previously considered a junior synonym of $P$. rostrata. The original description of $P$. dalmatina is based on an unspecified number of syntypes from "Dalmatien" collected by Kahr (SACHSE 1852). One syntype, a female, was located in the collections of the DEI; it is here designated as the lectotype. It is conspecific with P. picea and P. korgei.

P. korgei was introduced by LoHse (1974) as a nomen novum ("n. n.") [sic] for his previous interpretation of $P$. rostrata. However, according to the Code (ICZN 1999), his making this name available in a diagnostic key represents a species description. Since he does not specify any material or localities, all the specimens seen by him up to 1974 must be regarded as syntypes. A male from the Lohse collection is here designated as the lectotype.

Additional material examined: France: Poitou-Charentes: 1 ex., St.-Georges-de-Didonne, 18.VIII.1926 (cAss). Picardie: 1 ex., Oise, Laigneville, leg. Méquignon (MHNG); 1 ex., Laigneville, VII.1927 (cAss). Île-de-France: 1 ex., Paris (BMNH); 2 exs., 7 km SW Paris, Le Petit-Clamart ["Petit Bicètre"], VI.1903 (BMNH, cAss). Champagne-Ardenne: 1 ex., Haute-Marne, Saint-Dizier, leg. St.-Claire-Deville (MHNG). Provence: 1 ex., Cannes (NHMW); 1 ex., Var valley, 500-1500 m, 3.VI.1988, leg. Renner (cRen); 1 ex., Alpes-Maritimes, Var inundation, X.1953 (MHNG); 1 ex., Alpes-Maritimes, Breil, 1.VI.1955 (cAss); 1 ex., Alpes-Maritimes, III.1947 (MHNG); 1 ex., Alpes-Maritimes,"N. Vesubie", XI.1950 (MHNG); 1 ex., Bouches-du-Rhône, La Cayolle, VIII.1954, leg. Herve (MHNG).

Germany: Rheinland-Pfalz: 2 exs., Deidesheim (NHMW); 3 exs., Schloßböckelheim, car-net, 31.V.1996, leg. Köhler (cKöh); 1 ex., Ingelheim, Neumühle, arable land, 1993, leg. Köhler \& Fritz (cKöh); 1 ex., Bad Dürkheim, leg. Eppelsheim (DEI). Berlin/Brandenburg: 1 ex., Berlin (cVog).

Austria: Niederösterreich: 6 exs., Stockerau, leg. Bernhauer, etc. (FMNH, NHMW, cAss); 1 ex., Stockerau, 22.X.1898, leg. Bernhauer (FMNH); 10 exs., Bisamberg, leg. Luze, Skalitzky, etc. (FMNH, MHNG, NHMW, cAss); 3 exs., Kritzendorf, Donauauen (NHMW); 1 ex., Herzogenburg, leg. Grundmann (cAss); 2 exs., Horn (FMNH); 1 ex., L.-Enzersdorf, leg. Bernhauer (FMNH); 1 ex., Preßbaum, leg. Spaeth (FMNH); 1 ex., Dörnstein/Wachau, pitfall trap, IV.-V.1967, leg. Malicky (cAss); 1 ex., Hainburger Berge [ca. 48 $07^{\prime} \mathrm{N}$, 16 $\left.{ }^{\circ} 7^{\prime} \mathrm{E}\right]$ (NHMW); 1 ex., Frauenstein near Mödling, under stone, 6.IV.1941, leg. Scheerpeltz (cAss); 1 ex., Frauenstein near Mödling, leg. Scheerpeltz (MHNG); 1 ex., Eichkogel near Mödling, 27.IV.1950 (NHMW); 1 ex., Mödling env., leg. Scheerpeltz (NHMW); 1 ex., Altenburg (NHMW); 1 ex., Oberweiden (NHMW); 1 ex., Hundsheimer Kogel (NHMW). Wien: 1 ex., Rossauerlände, leg. Bernhauer (FMNH); 3 exs., Türkenschanze [ $48^{\circ} 14^{\prime} \mathrm{N}, 16^{\circ} 20^{\prime} \mathrm{E}$ ] (NHMW, cAss); 1 ex., Stammersdorf, hamster burrows at 1.0-1.25 m depth, 15.VII.1950, leg. Schweiger (cAss); 1 ex., Döbling, leg. Skalitzky (NHMW); 3 exs., Prater (NHMW, SMNS, cAss); 1 ex., Laaer Berg [48 $\left.10^{\prime} \mathrm{N}, 16^{\circ} 24^{\prime} \mathrm{E}\right]$ (NHMW); 5 exs., Wien env., leg. Breit, Schude, etc. (NHMW). Kärnten: 1 ex., Klagenfurt (FMNH). Burgenland: 1 ex., Neusiedl, 12.VII.1973 (cAss); 1 ex., Podersdorf, VII.1956, leg. Papperitz (SMNS); 1 ex., Neusiedlersee, Heide, 1.V.1953, leg. Schubert (NHMW); 1 ex., Neusiedlersee, N. S. Heide, 1.V.1953, leg. Schubert (NHMW); 2 exs., Neusiedlersee, leg. Schuster (NHMW). Locality not specified: 7 exs. (BMNH).

Italy: Veneto: 3 exs., Verona, San Massimo, in nest of Lasius niger, 30.III.1969, leg. Zanetti (cZan, cAss); 1 ex., Verona, Via Col Galliano, house, in nest of Tetramorium sp. in flower pot, 27.IV.1991, leg. Zanetti (cZan); 1 ex., Verona, Soave, in nest of Lasius emarginatus, 4.IV.1969, leg. Zanetti (cZan); 1 ex., Monti Lessini, Grezzana-Montecchio, car-net, 14.VI.1989, leg. Wunderle (cWun); 1 ex., Malcesine, 6.-18.V.1956, leg. Benick (cVog); 1 ex., Verona, Val d'Illasi, car-net, 31.V.2003, leg. Renner (cRen); 1 ex., Padova, periferia, 10.IV.1970, leg. Zanetti (cZan). Emilia-Romagna: 1 ex., Modena, 5.III.1897, leg. Fiori (FMNH). Umbria: 4 exs., Monte Cucco, Sigillo (PG), 20.VII.1975, leg. Rossi (cZan). Calabria: 1 ex., Aspromonte, 1905, leg. Paganetti (DEI).

Czech Republic: 1 ex., Č. Středohořy, Obřica-lom, 14.IV.1991, leg. Moravec (cAss). 
Slovakia: 1 ex., Trenčin, leg. Brancsik (FMNH); 3 exs., Bratislava, leg. Zoufal (NHMW).

Hungary: 1 ex., Villány-Siklós, V.1985, leg. Sieber (cVog); 5 exs., Tiszacsege, car-net, 11.-13.VII.2001, leg. Renner (cAss, cRen, cSch); 1 ex., Balaton, Tihany, 1961, leg. Smetana (BMNH).

Romania: 1 ex., Ploieşti, leg. Breit (NHMW).

Slovenia: 1 ex., Portorož, VI.1981, leg. Puthz (cAss); 1 ex., Savina, leg. Paganetti (MHNG); 3 exs., "Oberkrain", leg. Ludy (NHMW, cAss).

Croatia: 2 exs., Rijeka ["Fiume"] (NHMW); 5 exs., Učka, leg. Breit ["Mte. Maggiore"; 4515N, 14²12E (NHMW, cAss); 6 exs., Plitvice-Josibdol, car-net, 9.V.1990, leg. Wunderle (cWun); 7 exs., JosibdolKarlovac, car-net, 9.V.1990, leg. Wunderle (cWun, cAss); 1 ex., Vodice, car-net, 22.VI.2003, leg. Apfel
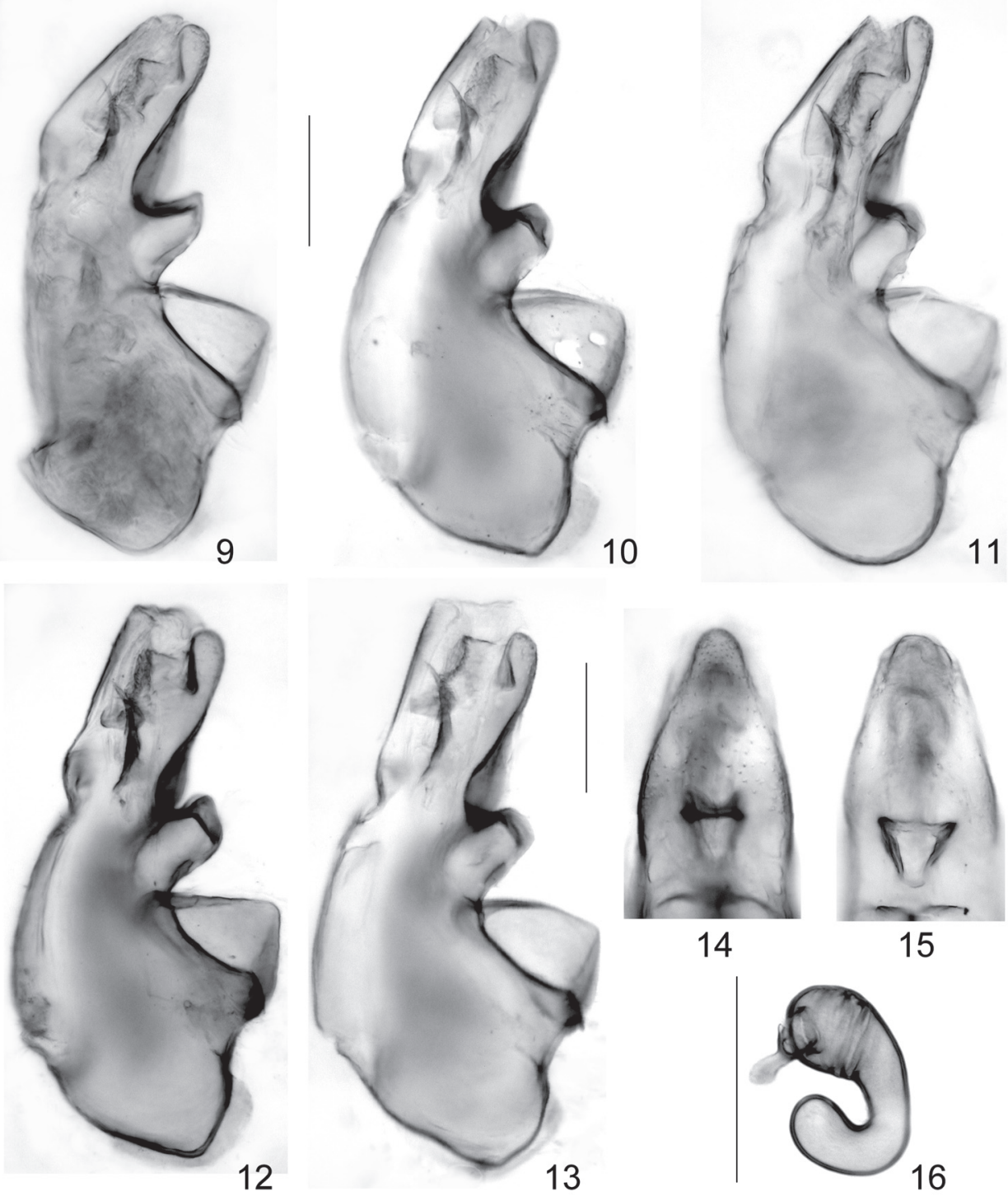

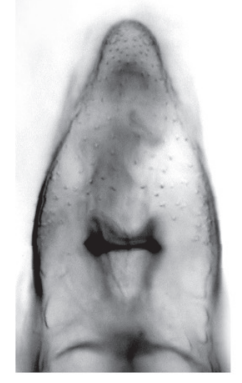

14

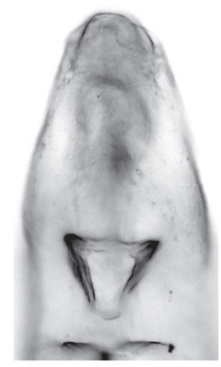

15

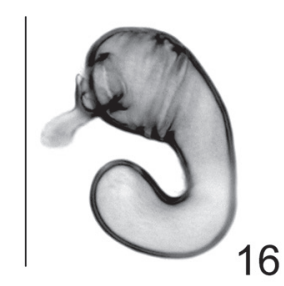

Figs 9-16: Pronomaea picea Heer: median lobe of aedeagus in lateral view (9-13) of males from France (9-10), Italy (11), Hungary (12), and Greece (13); apical part of median lobe of aedeagus in ventral view (14-15); spermatheca (16). Scale bars: $0.1 \mathrm{~mm}$. 
(cVog); 1 ex., Metkovi, 1879, leg. Reitter (NHMW); 1 ex., Krk island, leg. Mader (NHMW); 1 ex., Zadar ["Zara"] (NHMW); 1 ex., Split, Mosor [ $43^{\circ} 30 \mathrm{~N}, 16^{\circ} 40 \mathrm{E}$ ], leg. Mader (NHMW); 1 ex., Starigrad [ $44^{\circ} 48^{\prime} \mathrm{N}$, 145'ㄹ], leg. Breit (NHMW); 1 ex., Krk island ["Ins. Veglia"], 1879, leg. Reitter (NHMW); 1 ex., Brač island ["Brazza"], S. Pietro, 3.VII.1920, leg. Novak (DEI); 1 ex., Korčula, Brdo Sv. Marko, 250 m, soil under olive, 20.VI.2007, leg. Čeplik (cAss); 1 ex., "Croatia", leg. Apfelbeck (NHMW); 1 ex., "Dalmatia" (NHMW); 1 ex., locality illegible (NHMW).

Yugoslavia: 1 ex., Serbia, Fruska Gora, leg. Paganetti (FMNH).

Bosnia-Herzegovina: 1 ex., Vlašić planina, 600-1700 m, car-net, 5.V.1990, leg. Wunderle (cAss); 2 exs., Jablanica, 1901 (DEI, NHMW); 1 ex., Trebinje, 1903, leg. Leonhard (NHMW); 1 ex., "Hercegowina", leg. Kaufmann (NHMW).

Montenegro: 5 exs., Herceg-Novi, leg. Paganetti, etc. (FMNH, MHNG, NHMW); 3 exs., Savina [42²7N, $\left.18^{\circ} 33 \mathrm{E}\right]$, leg. Paganetti (FMNH); 2 exs., Budva, leg. Paganetti (DEI); 1 ex., Budva (FMNH); 1 ex., Radostak [42 $\left.30^{\prime} \mathrm{N}, 18^{\circ} 34^{\prime} \mathrm{E}\right]$, leg. Holdhaus (cAss).

Bulgaria: 1 ex., Rupite near General Todorov, 6.V.1984, leg. Hieke (cVog).

Albania: 4 exs., Elbasan (NHMW, cAss).

Greece: 1 ex., Thessalia, Volo (NHMW); 1 ex., Thessaloniki, leg. Schatzmayr (DEI); 2 exs., Thessaloniki (BMNH, cAss); 2 exs., Makedhonia, Athos, leg. Schatzmayr (DEI); 1 ex., Pelopónnisos, Nauplia, leg. von Bruck (cAss); 2 exs., Pelopónnisos, Taygetos, leg. Rottenberg, etc. (NHMW); 1 ex., Taygetos, leg. Brenske (DEI); 1 ex., Pelopónnisos, locality not specified (NHMW); 4 exs., Levkás, Karia env., 600 m, dark stream valley, leaf litter sifted, 25.IX.1993, leg. Assing (cAss); 1 ex., Zákinthos, near Zákinthos town, 1909, leg. Hilf (DEI); 1 ex., Corfu, VII.1902, leg. Cameron (BMNH); 1 ex., Ikaria, Nas, 37³7'N, 36 03'E, 10-100 m, grass under Mastix shrub sifted, 26.IV.2003, leg. Brachat \& Meybohm (cAss); 1 ex., Límnos, leg. Cameron (BMNH); 6 exs., "Graecia" (DEI, NHMW).

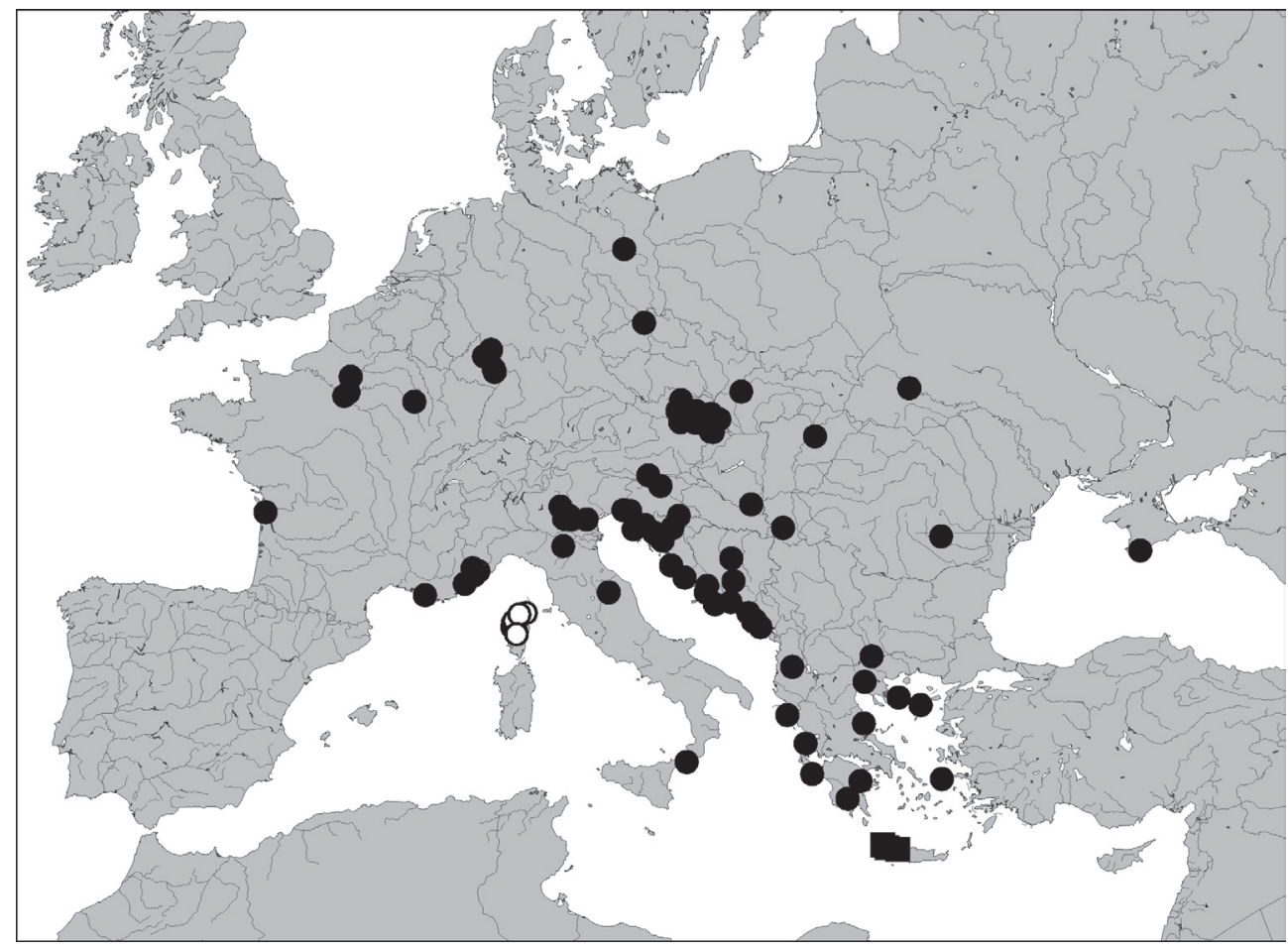

Map 2: Distributions of Pronomaea picea Heer (filled circles), P. corsicana sp. $\mathrm{n}$. (open circles), and P. wunderlei sp. n. (squares), based on examined records. The records of doubtful identity from Malta are omitted. 
Ukraine: 4 exs., Crimean peninsula, Iaila range, leg. Knirsch, Winkler (FMNH, MHNG, NHMW); 1 ex., Podole Dobrowlany, 11.VII.1931, leg. Tenenbaum (FMNH).

Identification uncertain: Malta: 1 \% , NE Mtarfa, Chadwick lake, dry streambed, 27.II.1997, leg. Schwartz (cSch); 1 우, locality not specified, leg. Cameron (BMNH).

\section{Diagnosis:}

3.0-3.9 mm. Coloration and other external characters similar to those of P. rostrata and also subject to considerable intraspecific variation, distinguished only as follows:

Coloration of basal antennomeres usually (but not always!) paler, reddish yellow to pale brown, than remainder of antenna; coloration of elytra and legs on average paler brown. Puncturation of forebody on average slightly denser and finer. Pronotum smaller in relation to head and more slender; 1.1-1.2 times as wide as long and 1.2-1.3 times as wide as head, rarely broader. Pronotal pubescence slightly longer and less depressed.

$\sigma^{\star}$ : median lobe of aedeagus $0.40-0.42 \mathrm{~mm}$ long, broader than in P. rostrata in ventral view and with pronounced projection at base of ventral process in lateral view, this projection more or less truncate apically (Figs 9-15).

+ : spermatheca with distinctly shorter duct (Fig. 16).

\section{Comparative notes:}

From all its congeners, $P$. picea is readily distinguished by the conspicuous morphology of the median lobe of the aedeagus. From $P$. rostrata, the only species whose distribution overlaps with that of $P$. picea, it is also reliably separated by the distinctly shorter duct of the spermatheca. For additional external characters see the diagnosis above.

\section{Distribution and bionomics:}

Pronomaea picea apparently has a Ponto-Mediterranean distribution. It is present in practically all of the Balkans, in the south of Central Europe, in practically all of the Italian mainland and in the north of Western Europe. Like P. rostrata, it has not been reported from the British Isles and Scandinavia. FAGEL (1969) indicates some additional records (as P. rostrata), at least the following of which are zoogeographically plausible: Belgium (Dampicourt), Italy (Piemonte), Romania (Dobrudja), and Greece (Evvoia). Also, it seems safe to assume that the records of $P$. rostrata from Corfu and Thássos by Coiffait (1976) refer to P. picea. Previous records (as P. korgei) from Spain and especially Portugal (Smetana 2004) are highly unlikely to refer to this species, although a presence in the very northeast of Spain would seem possible; in any case, a confirmed record from the Iberian Peninsula is currently unknown. The record from Malta is based only on females and may refer to $P$. sicula.

The ecological data specified on the labels of the material examined are so diverse that conclusions regarding the real habitat of this species are difficult. The specimens listed above were collected on arable land, on river banks, in flood debris (October), under stones, in soil under olive trees, sifted from leaf litter in stream valleys and from Mastix litter, and found in hamster burrows and in nests of various ant species (Lasius niger, L. emarginatus, Tetramorium sp.). The record of several specimens in fox burrows in southeastern Austria (Burgenland) by Franz (1938) almost certainly refers to this species. The altitudes range from near sea-level up to approximately $1500 \mathrm{~m}$. In contrast to $P$. rostrata, it has been collected on the wing (car-net) on several occasions in May (5 samples), June (3 samples), and July (1 sample), suggesting that $P$. picea is an active flyer. Adult beetles have been observed from March to November, with a maximum during the period from April through July: March (7 specimens/4 samples); April (7/7); May (29/11); June (6/6); July (17/8); August (2/2); September (4/1); October (2/2); November (1/1). 
Pronomaea corsicana sp. n. (Figs 17-25, Map 2)

\section{Type material:}

Holotype ơ: "France - Korsika, Col de Vergio (30 km W Corte), 1600 m, Gesiebe, 9.4.1990, leg. Assing / Holotypus o Pronomaea corsicana sp. n. det. V. Assing 2007" (cAss). Paratypes: 2 o $~$ : same data as holotype (cAss); 6 exs.: "'Bastia, Corse, V.60 / Coll. J. Ochs in Col. M. Curti, MHNG 1991" (MHNG, cAss); 5 exs.: "Bastia mer., 31.VI.55 / Coll. J. Ochs in Col. M. Curti, MHNG 1991" (MHNG, cAss); 1 ex.: "Bastia mer., VII.54 / Coll. J. Ochs in Col. M. Curti, MHNG - 1991" (MHNG); $10^{\star}$ : "F: Corse, Haut-Asco, 2020 m, am 2. See, 27.7.1994, leg. Zerche" (DEI); $20^{\star} 0^{\star}$ : "Corsica, Haute Asco, m 1550, muschi ruscello, 29.VII.80, Sette" (cZan, cAss); ); 1 : : "Corsica, Haute Asco, m 1500, 28.VII.1976, leg. Sette" (cZan); 1 \% : "Corsica, foresta di Tartagine, m 750, 27.VII.80, Sette" (cZan); 1 9 : "Corsica, Valle Restonica, m 1600, 4.VIII.80, Sette" (cZan); 1 ㅇ: "Cors. Piraldo, Desert des Agriates, 12.VIII.79, Sette" (cZan); 1 ex.: "Corsica" (FMNH); $10^{\star}, 1$ ㅇ: "Bocognano (20), 23.5.72, au vol, 16/17h, D27 [road number]" (cTro).

\section{Description:}

Habitus as in Fig. 17. Highly similar to P. picea; distinguished only by the darker coloration and the morphology of the aedeagus. Coloration of body blackish; legs usually dark brown; antennae uniformly dark brown to blackish, basal antennomeres at most only slightly paler than remainder of antennae. External characters as in P. picea; distinguished only by the morphology of the aedeagus.

$\sigma^{*}$ : median lobe of aedeagus $0.40-0.42 \mathrm{~mm}$ long similar to that of $P$. picea, but basal projection of ventral process acute or rounded apically, not truncate (Figs 18-24).

+ : spermatheca similar to that of P. picea (Fig. 25)

Etymology: The name (adjective) is derived from Corsica, where the species is apparently endemic.

\section{Comparative notes:}

From other Pronomaea species, except P. picea, $P$. corsicana is readily distinguished by the pronounced projection at the base of the ventral process of the aedeagus (lateral view). In contrast to $P$. picea, this projection is apically acute or rounded, not truncate. A comparison of males of $P$. picea and $P$. corsicana from various localities suggests that this difference is constant (compare Figs 9-13 and 18-23).

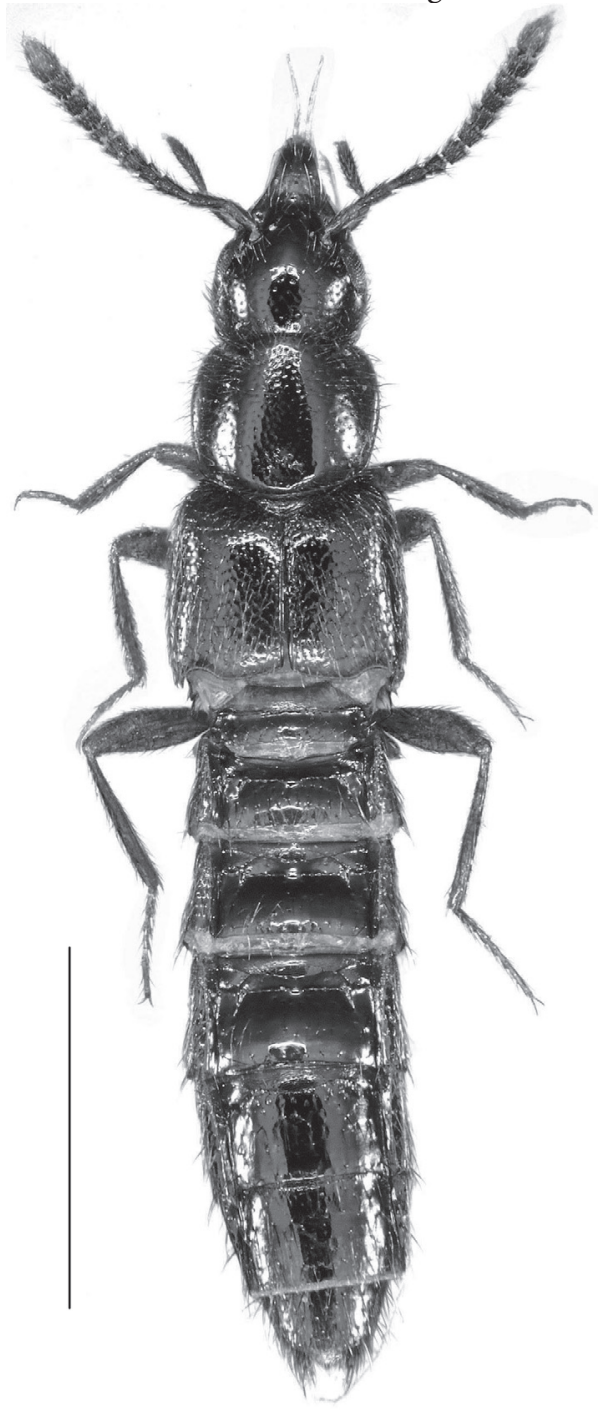

Fig. 17: Pronomaea corsicana sp. n.: habitus (photo by Marc Tronquet). Scale bar: $1.0 \mathrm{~mm}$. 

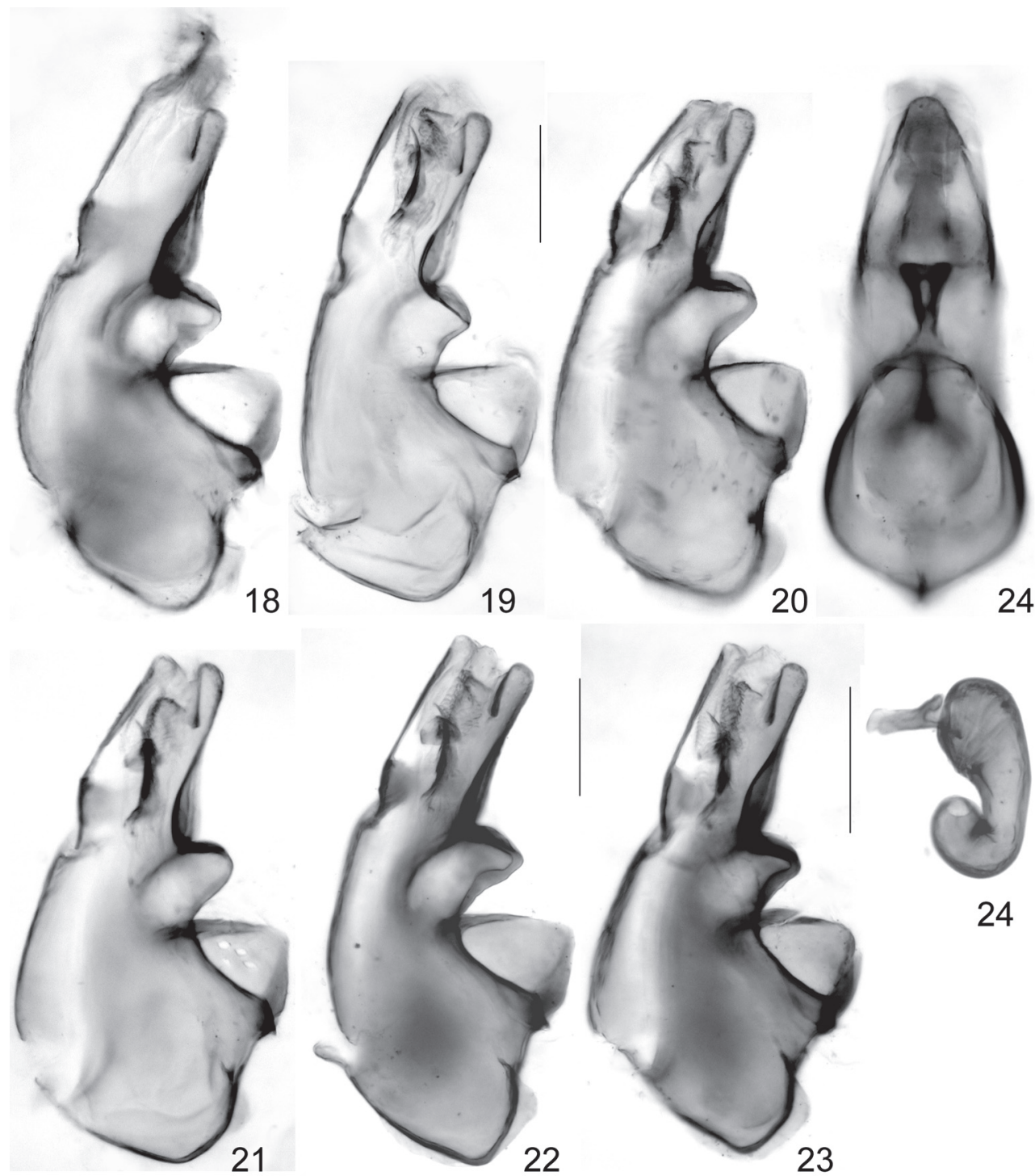

Figs 18-25: Pronomaea corsicana sp. n.: median lobe of aedeagus in lateral view (18-23) of males from various Corsican localities; median lobe of aedeagus in ventral view (24); spermatheca (25). Scale bars: $0.1 \mathrm{~mm}$.

\section{Distribution and bionomics:}

Pronomaea corsicana is apparently endemic to Corsica (Map 2). Previous records of P. rostrata from this island probably refer to this species, at least in part. The type specimens were collected at altitudes of up to $2020 \mathrm{~m}$, some of them were sifted from the litter of subalpine shrubs or found in moss near streams, during the period from April through August. Two specimens were caught on the wing (car-net) in May. 
Pronomaea wunderlei sp. n. (Figs 26-28, Map 2)

\section{Type material:}

Holotype ơ:"GR W-Kreta, Deres, 500 m, Bachmoos, Kastanie, 13.10.91, Wunderle / Holotypus ơ Pronomaea wunderlei sp. n. det. V. Assing 2007" (cAss). Paratypes: $10^{\text {t: }}$ "Kreta, Paganetti / rostrata det. Bernhauer, Chicago NHMus. M. Bernhauer Collection" (FMNH); $10^{\text {t: }}$ "Crète env. Kerá, 9.VIII.72, S. Vit" (MHNG); $10^{*}$ : "23.3.73, West-Kreta, Limni Kourna, DrFülscher Meybohm" (cAss).

\section{Description:}

External characters as in P. picea; distinguished only by the morphology of the aedeagus.

$\sigma^{7}$ : median lobe of aedeagus $0.44-0.45 \mathrm{~mm}$ long, similar to that of $P$. rostrata, but apex of different shape, flagellum slightly longer, and projection at base of ventral process much closer to crista apicalis (Figs 26-28).

क: unknown.

Etymology: The species is dedicated to my friend and colleague Paul Wunderle, who collected the holotype.

\section{Comparative notes:}

From other Pronomaea species, $P$. wunderlei is reliably distinguished only by the distinctive shape of the median lobe of the aedeagus.

\section{Distribution and bionomics:}

The known distribution of $P$. wunderlei is confined to three localities in western Crete (plus an unspecified locality), where it is apparently endemic and the only representative of the genus (Map 2). The record of $P$. rostrata by ScheERPelTz (1964) refers to this species. The holotype was collected from moss at a stream at an altitude of $500 \mathrm{~m}$. The type specimens were taken in March, August, and October. Additional bionomic data are not available.

Pronomaea sicula sp. n. (Figs 29-31, Map 1)

\section{Type material:}

Holotype o": "Sicilia 1906, Ficuzza, O. Leonhard / Pronomaea rostrata / coll. DEI Müncheberg / Holotypus ơ Pronomaea sicula sp. n. det. V. Assing 2007" (DEI). Paratypes: $10^{\text {T}}$ : same data as holotype (cAss); $10^{*}:$ "F. Tellaroi (SR), 800 m, d. foce, 7.8.90, Sabella" (cZan); 1 우: " o / Sicilien - Ficuzza, 18.4.42 / rostrata / ex coll. Scheerpeltz" (NHMW); 1 \%: "Ciccia [=Monte Ciccia, $\left.38^{\circ} 15^{\prime} \mathrm{N}, 15^{\circ} 32^{\prime} \mathrm{E}\right], 25 . V I I I .32$, F. Vitale / rostrata Er. det. Bernhauer" (FMNH).

\section{Description:}

External characters as in P. picea; distinguished only by the morphology of the aedeagus.

$0^{*}$ : median lobe of aedeagus approximately $0.42 \mathrm{~mm}$ long; general morphology similar to that of P. picea, but ventral process more slender in ventral view, in lateral view more strongly bent, apex of ventral process more slender, and projection at base of of ventral process much less prominent (Figs 29-31).

Q: spermatheca similar to those of P. picea and $P$. corsicana. 

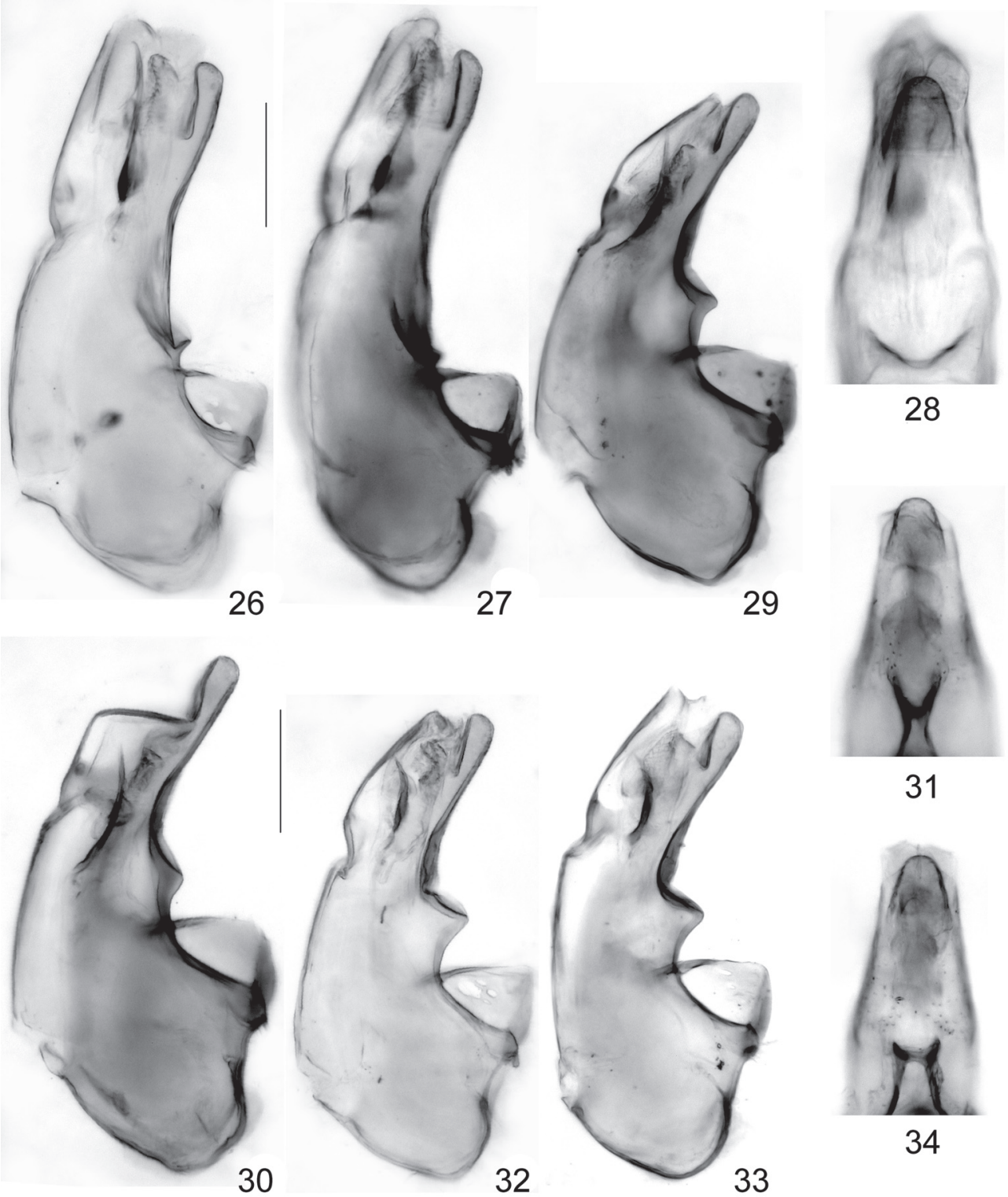

Figs 26-34: Pronomaea wunderlei sp. n. (26-28), P. sicula sp. n. (29-31), and P. sardoa sp. n. (32-34): median lobe of aedeagus in lateral view $(26-27,29-30,32-33)$ of holotypes $(26,29,32)$ and paratypes $(27,30,33)$; apical part of median lobe of aedeagus in ventral view $(28,31,34)$. Scale bars: $0.1 \mathrm{~mm}$.

Etymology: The name (Latin, adjective) is derived from the name of the island where the species is endemic.

\section{Comparative notes:}

From other Pronomaea species, P. sicula is reliably distinguished only by the distinctive shape of the median lobe of the aedeagus. The latter is most similar to that of $P$. sardoa; for distinguishing characters see the comparative notes in the following section. 


\section{Distribution and bionomics:}

Pronomaea sicula is apparently endemic to Sicily, where it is evidently the only representative of the genus (Map 1). The record of P. rostrata by Scheerpeltz (1965) refers to this species. Two paratypes were collected in August, one of them in a stream valley at an altitude of $800 \mathrm{~m}$, another one apparently on a river bank. Additional bionomic data are not available.

\section{Pronomaea sardoa sp. n. (Figs 32-34, Map 1)}

\section{Type material:}

Holotype ơ : "I-Sardinia, 5, XI.85, H. Winkler / Holotypus ơ Pronomaea sardoa sp. n. det. V. Assing 2007" (cAss). Paratypes: $10^{\star}$ : "Sinnai (CA), Riu longu, 15.VI.1974, Meloni" (cZan); 1 : "9.9.92, Sardinien, Lago Coghinas, leg. Wunderle" (cWun); 1 ex.: "Sorgono, Sardinien, 1911 [name of collector illegible]" (SMNS).

\section{Description:}

External characters as in P. picea; distinguished only by the morphology of the aedeagus.

$\sigma^{*}$ : median lobe of aedeagus small, approximately $0.38 \mathrm{~mm}$ long; general morphology similar to that of $P$. picea, but ventral process more slender in ventral view, in lateral view more strongly bent, apex of ventral process more slender, and projection at base of of ventral process much less prominent (Figs 32-34).

i : spermatheca similar to those of $P$. picea and P. corsicana.

Etymology: The name (Latin, adjective) is derived from the name of the island where the species is endemic.

\section{Comparative notes:}

The aedeagus of $P$. sardoa is most similar to that of $P$. sicula, but distinguished by smaller size, a less slender apex of the ventral process, the more pronounced angular projection at the base of the ventral process, and by the shorter flagellum in the internal sac.

\section{Distribution and bionomics:}

The species is the only representative of the genus in Sardinia, where it appears to be endemic (Map 1). The types were collected in June, September, and November, one of them apparently on a lake shore. Additional bionomic data are not available.

\section{Pronomaea araxicola ReITTER, 1898 (Figs 35-40, Map 3)}

Pronomaea araxicola ReITTER, 1898: $114 \mathrm{f}$.

Pronomaea subterranea Iablokoff-Khnzorian, 1957: 292; synonymy by Semenov (2003).

Pronomaea libanotica Fagel, 1969: 29 f.; syn. n.

Pronomaea orientalis Fagel, 1969: 30 f.; syn. $\mathbf{n}$.

\section{Type material examined:}

P. araxicola: Lectotype $\sigma^{*}$, here designated: "Caucasus, Araxesthal, Leder. Reitter / araxicola m. [remainder illegible] / c. Epplsh. Steind. d. / Typus / Lectotypus ơ Pronomaea araxicola Reitter, desig. V. Assing 2007 / Pronomaea araxicola Reitter det. V. Assing 2007" (NHMW). Paralectotype i : same data as lectotype (NHMW). 
P. libanotica: Holotype $0^{\star}$ : "Liban: Nabeh Safa, bois marécageux, 1000 m, V.1966, G. Fagel / G. Fagel det. libanotica n. sp. / Type / Pronomaea libanotica Fagel det. V. Assing 2007" (IRSNB).

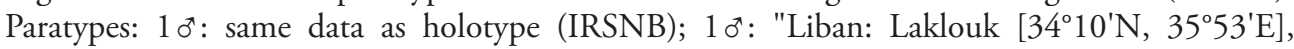
1500-1800 m, V.1964, G. Fagel / G. Fagel det. libanotica n. sp. / Paratype / Pronomaea libanotica Fagel det. V. Assing 2007" (IRSNB).

P. orientalis: Holotype $\sigma^{*}$ : "Anatolie mér., Antalya, V.1968, G. Fagel / G. Fagel det. orientalis n. sp. / Type / Pronomaea libanotica Fagel det. V. Assing 2007" (IRSNB). Paratypes: $30^{\star} o^{\star}$ : same data as holotype (IRSNB).

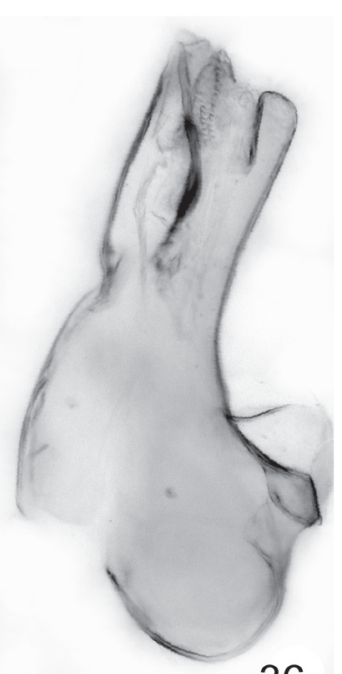

36
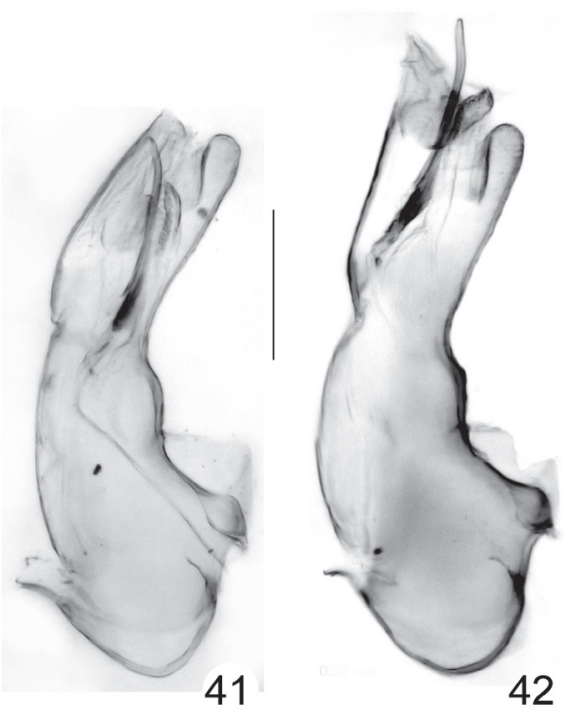

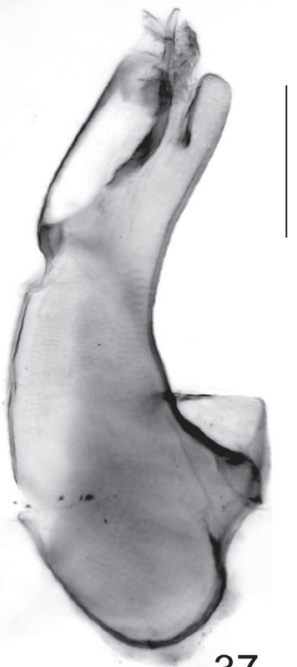

37

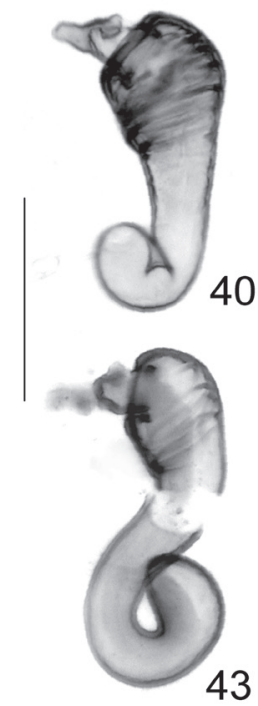

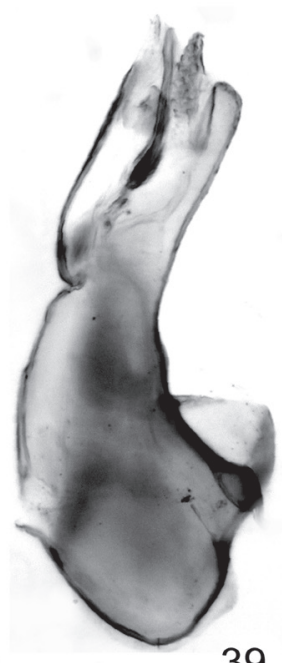

39

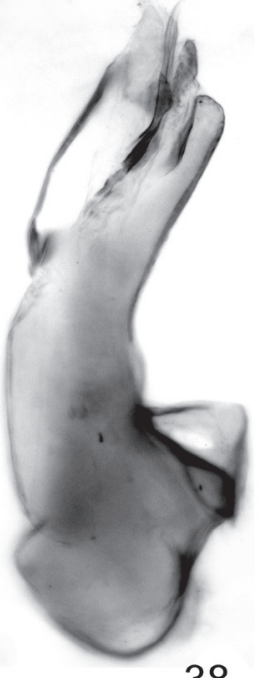

38

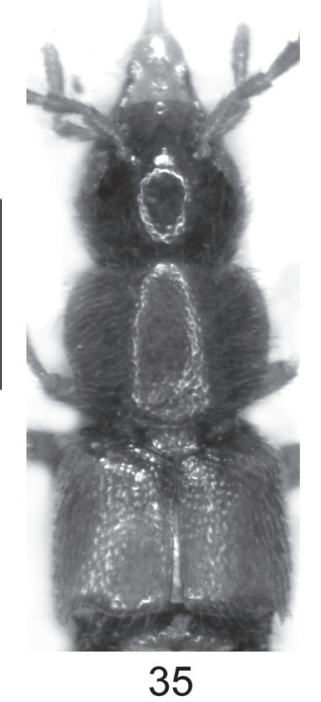

Figs 35-43: Pronomaea araxicola ReitTer (35-40) and P. spalacis sp. n. (41-43): forebody of paratype of P. orientalis (35); median lobe of aedeagus in lateral view (36-39, 41-42) of male from "Araxesthal" (36), holotype of P. libanotica (37), holotype of P. orientalis (38), male from Antakya (39), and paratypes of P. spalacis (41-42); spermatheca (40, 43). Scale bars: $35: 0.5 \mathrm{~mm}$; 36-43: $0.1 \mathrm{~mm}$. 


\section{Comments:}

Pronomaea araxicola was described from an unspecified number of syntypes from "Araxesthal bei Ordubad" and one specimen from "Syrien" (Reitter 1898). Two of these syntypes were located in the collections of the NHMW; the male is here designated as the lectotype. According to Semenov (2003) two additional syntypes, now paralectotypes, are housed in the Hungarian Natural History Museum in Budapest.

The original description of P. libanotica is based on a holotype male and a male paratype from "Liban: Nabeh Safa, 1000 m, dans l'humus en bois marécageux", as well as a paratype from "Liban: Laklouk, 1500-1800 m, sous pierre sur sol détrempé par neige fondue". Pronomaea orientalis was described from a holotype male and three male paratypes from "Anatolie méridionale: Antalya, parmi les racines de plantes, au pied d'un peuplier au sommet des falaises du bord de mer" (FAgel 1969). According to FAgel (1969), P. orientalis is distinguished from P. libanotica by paler coloration, more transverse preapical antennomeres, and a differently shaped pronotum; there is no reference to $P$. araxicola in either of the original descriptions. A comparison of the type specimens of both Fagel names and of $P$. araxicola revealed that they are conspecific; their genitalia are identical (Figs 36-38). Therefore, both P. libanotica and P. orientalis are here placed in the synonymy of the senior name $P$. araxicola.

Additional material examined: Turkey: Kahramanmaraş: 1 ex., $34 \mathrm{~km} \mathrm{SW}$ Kahramanmaraş, $37^{\circ} 23^{\prime} \mathrm{N}$, $36^{\circ} 41^{\prime} \mathrm{E}, 1070 \mathrm{~m}$, litter of oak and shrubs and grass roots sifted, 12.IV.2004, leg. Assing (cAss). Antakya: 4 exs., 7 km E Yeşilkent, 350-400 m, 4.V.1978, leg. Besuchet \& Löbl (MHNG, cAss).

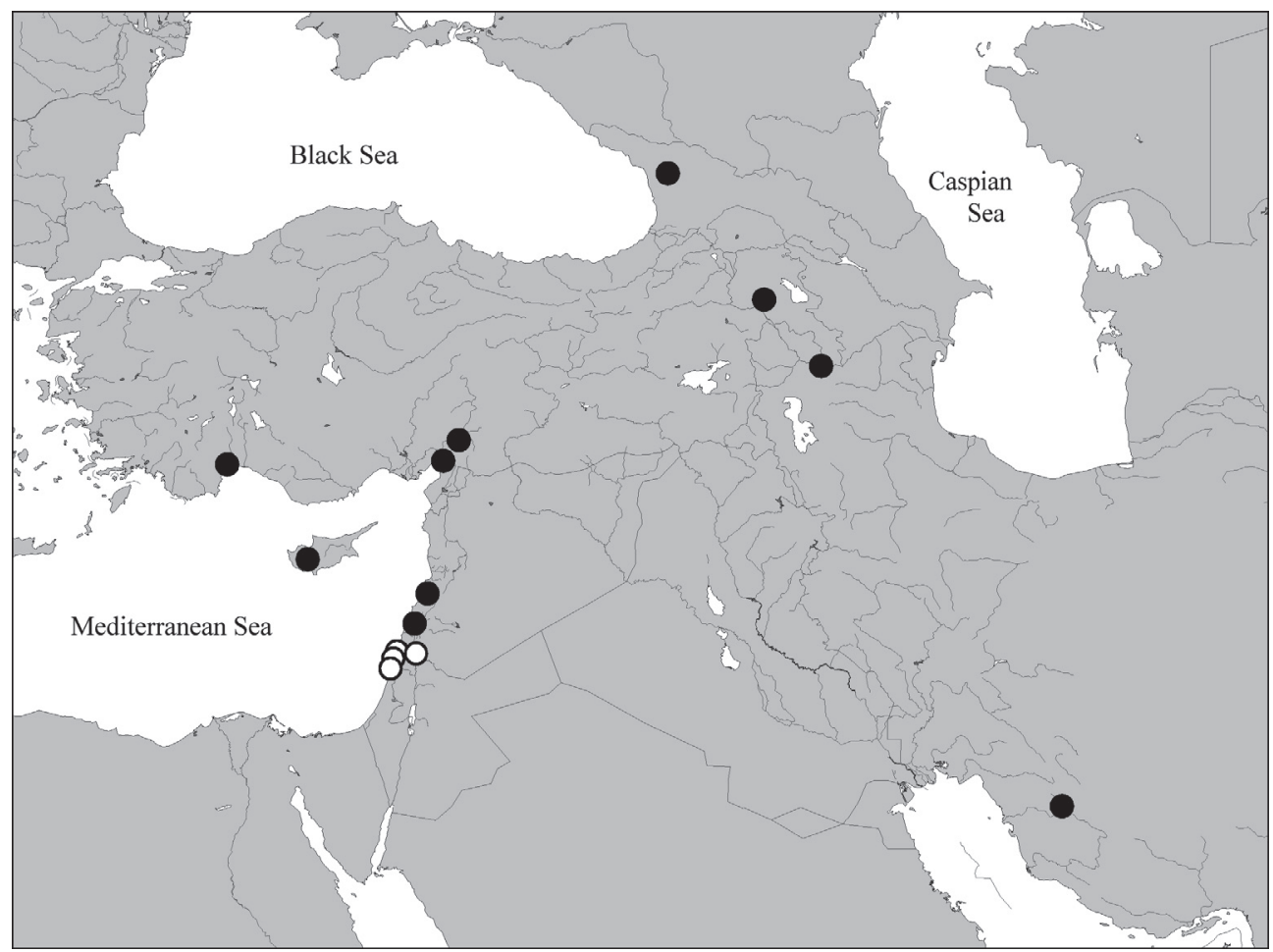

Map 3: Distributions of Pronomaea araxicola ReItTer (filled circles) and P. spalacis sp. n. (open circles), based on examined and literature records. The unconfirmed record of $P$. araxicola from Bolu (Turkey) is omitted. 
Cyprus: 1 ex., Agios Dhimitrios, 600 m, 9.VII.1977, leg. Besuchet (MHNG).

Georgia: 1 ex., W-Caucasus, "Landschaft Letschgum", leg. Leder (NHMW).

Azerbaijan: 3 exs., Ordubad ["Araxesthal"], leg. Leder \& Reitter (DEI, NHMW, cAss).

Iran: 1 ex., Fars province, ca. $50 \mathrm{~km} \mathrm{SW}$ Shiraz, Richi, $29^{\circ} 30^{\prime} \mathrm{N}, 52^{\circ} 11^{\prime} \mathrm{E}, 1650 \mathrm{~m}$, 9.IV.2006, leg. Frisch \& Serri (MNHUB).

\section{Diagnosis:}

In external appearance similar to $P$. picea, but distinguished as follows:

Coloration paler: body rufous to brown, with most of abdominal tergite VI, anterior half of tergite VII, and often also the anterior median parts of tergites III-V darker.

Eyes smaller and less prominent; shorter than postocular region in dorsal view. Pronotum less convex in cross-section. Puncturation of head and pronotum on average finer, that of the pronotum on average denser. Elytra slightly shorter (Fig. 35).

$0^{\star}$ : median lobe of aedeagus smaller, $0.35-0.38 \mathrm{~mm}$ long, without projection at base of ventral process; apex of ventral process obliquely truncate (Figs 36-39).

ㅇ: spermatheca of similar shape as in P. picea (Fig. 40).

\section{Comparative notes:}

From all its Western Palaearctic congeners, P. araxicola is distinguished by the paler average coloration, the smaller eyes, the less convex (cross-section) pronotum, and by the morphology of the aedeagus. The latter is most similar to that of P. spalacis; for distinguishing characters see the following section.

\section{Distribution and bionomics:}

Pronomaea araxicola had previously been reported only from Armenia, Azerbaijan, and the Russian South European territory (Semenov 2003; Smetana 2004). Korge (1964) reported it from Bolu in northern Turkey, a record omitted in SMETANA (2004) and requiring confirmation. The above first records from Georgia, Cyprus, Lebanon, and Iran expand the known distribution considerably; it now ranges from the Caucasus region to Cyprus, the Lebanon, and Iran (Map 3).

As far as can be inferred from the labels of the examined specimens, they were collected in damp forests, in litter of oak and shrubs, on river banks, in poplar litter near the coast, and under stones, with the altitudes ranging from near sea-level to at least $1650 \mathrm{~m}$. On one occasion (types of $P$. orientialis), it was found together with $P$. anatolica. Those specimens with labels specifying the dates of collection were taken in April, May, and July.

Pronomaea spalacis sp. n. (Figs 41-43, Map 3)

\section{Type material:}

Holotype ơ: "Palästina, Prof. Dr. O. Theodor / Nest von Spalax, Acre [=Akko] Junctio 545, 19.2.1954 / rostrata, ex. coll. Scheerpeltz / Holotypus ơ Pronomaea spalacis sp. n. det. V. Assing 2007" (NHMW). Paratypes: 4 exs.: same data as holotype (NHMW, cAss); $10^{\star}:$ "v. picea Heer, Caifa, Syria, ded. Simon / var. picea Heer / c. Epplsh. Steind. d." (NHMW); $10^{\star}$ : "Israel: côte, Maagan Mikhael, 16.IV.82, Besuchet, Löbl" (MHNG); 1 : : Israel (North District), Upper Galilee, N. shore of Sea of Galilee, 200 m, Kfar Nakhum (Capernaum), 32 $53.011^{\prime} \mathrm{N}$, $035^{\circ} 34.707^{\prime} \mathrm{E}$, shore with stones and gravel, 22.IV.2006, D. W. Wrase [4]" (cSch). 


\section{Description:}

External characters extremely similar to those of $P$. araxicola; coloration as in dark-coloured specimens of $P$. araxicola. Distinguished only by the morphology of the aedeagus.

$O^{x}$ : median lobe of aedeagus of similar size and shape as that of $P$. araxicola, but base of ventral process bulging, apex of ventral process rounded in lateral view, apical internal structure of different shape, and flagellum longer and more slender (Figs 41-42).

i : spermatheca similar to those of P. picea, P. araxicola, and allied species (Fig. 43).

Etymology: The name (Latin, noun, genitive) refers to the fact that the holotype and several paratypes were collected in the nest of mole rat Spalax ehrenbergi.

\section{Comparative notes:}

From all Western Palaearctic Pronomaea species, except $P$. araxicola, P. spalacis is separated by smaller eyes, denser puncturation of the pronotum, the less convex (cross-section) pronotum, the paler average coloration, and the shape of the aedeagus. The latter is similar to that of $P$. araxicola, but distinguished by the bulging base of the ventral process (lateral view), the rounded apex of the ventral process (lateral view), the longer and more slender flagellum, and the different shape of the apical internal structure.

\section{Distribution and bionomics:}

The known distribution is confined to Israel (Map 3). Most of the types were collected in a nest of the mole rat Spalax ehrenbergi, one of the paratypes also on a lake shore with gravel, in February and April.

Pronomaea anatolica FAGEL, 1969 (Figs 44-47, Map 4)

Pronomaea anatolica FAGEL, 1969: $31 \mathrm{f}$.

\section{Type material examined:}

Holotype ơ: "Anatolie mér., Antalya, V.1968, G. Fagel / G. Fagel det. anatolica n. sp. / Type / Pronomaea anatolica Fagel det. V. Assing 2007" (IRSNB). Paratypes: $10^{\star}, 2$ ㅇ 우: "Anatolie mér., Alanya: Dim Irmak, VI.1968, G. Fagel / G. Fagel det. anatolica n. sp. / Paratype / Pronomaea anatolica Fagel det. V. Assing 2007" (IRSNB).

\section{Comments:}

The original description is based on a holotype male from "Anatolie méridionale: Antalya, au pied d'un peuplier au sommet des falaises du bord de mer" and three paratypes (one male and two females) from "Anatolie méridionale: Alanya, dans détritus végétaux sur plages du Dim Irmak" (FAGEL 1969).

Additional material examined: Bulgaria: 1 ex., Chirpan ["Tschirpan"; 42²' $\mathrm{N}, 25^{\circ} 20^{\prime} \mathrm{E}$ ], III.1941, leg. Schubert (NHMW).

Turkey: Muğla: 4 exs., 70 km NE Fethiye, Seki, above Temel, 3644'N, 293', 2225 m, snow field, 8.VII.2002, leg. Assing (cAss); 20 exs., Gölgeli Dağları, 20 km NE Köyceğız, above Ağla, 3703'N, 2849'E, $1690 \mathrm{~m}, 6 . X .2002$, leg. Assing (cAss). Isparta: 7 exs., Anamasdağ $\left[37^{\circ} 47^{\prime} \mathrm{N}, 31^{\circ} 13^{\prime} \mathrm{E}\right]$, leg. Weirather (MHNG, cAss). Antalya: 1 ex., N Kalkar, Dumanlı, Dağı, 36 24' N, 29 $26^{\circ} \mathrm{E}, 1230 \mathrm{~m}$, pine-cedar forest,

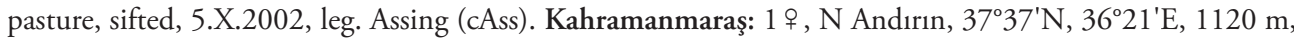
stream bank, flood debris sifted, 26.III.2005, leg. Assing (cAss); 1 ㅇ, $10 \mathrm{~km} \mathrm{~N}$ Andırın, road to Çokak, $37^{\circ} 39^{\prime} \mathrm{N}, 36^{\circ} 21^{\prime} \mathrm{E}, 1150 \mathrm{~m}, 1 .-2 . V .2005$, leg. Brachat \& Meybohm (cAss). 

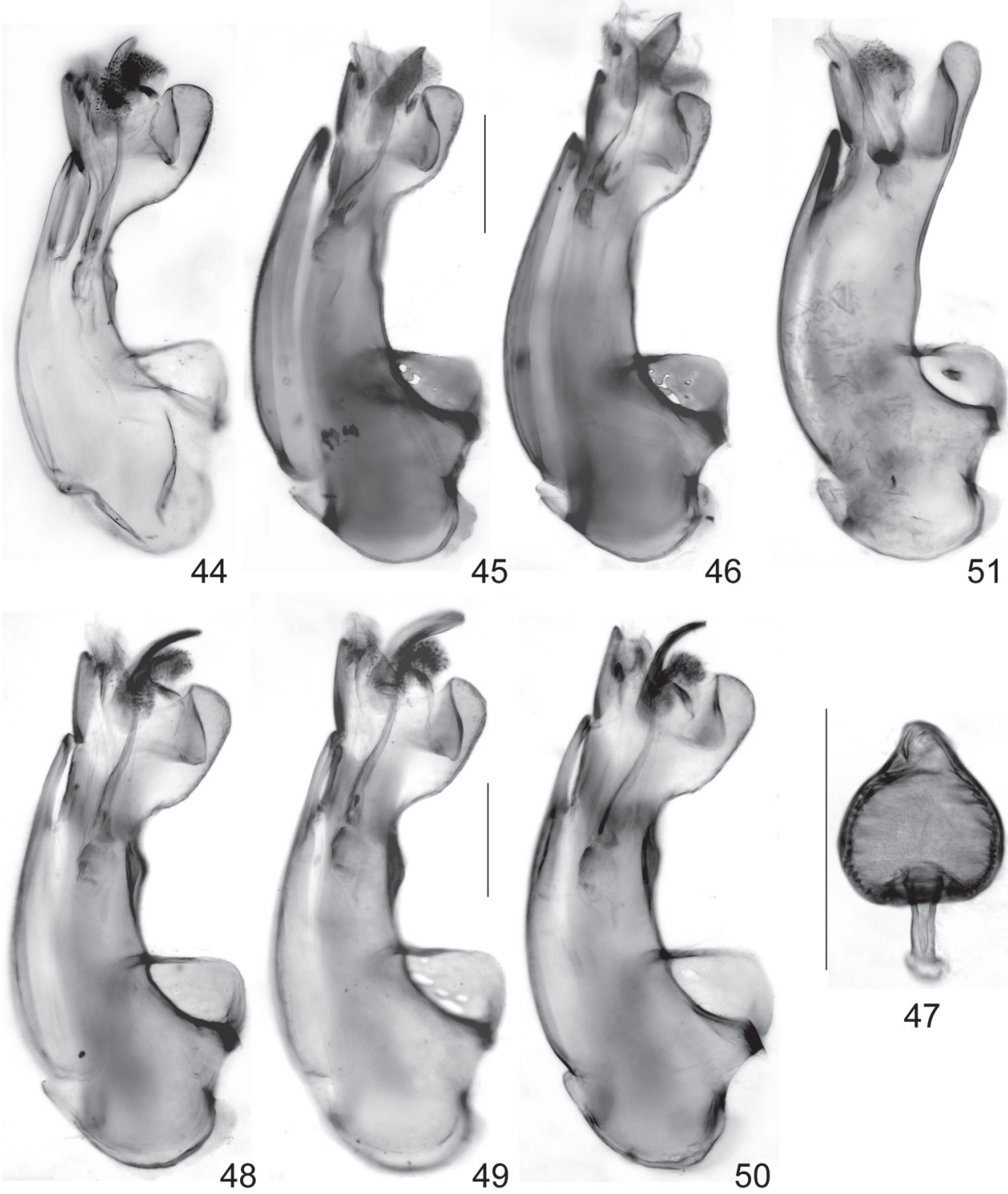

47

Figs 44-51: Pronomaea anatolica FAgel (44-47), P. khnzoriani Semenov (48-50), and P. flavirostris SEMENOV (51): median lobe of aedeagus in lateral view (44-46, 48-51) of holotype (44) and of males from Muğla (45-46), Iran (48-49), Amasya (50), and Tajikistan (51); spermatheca (47). Scale bars: $0.1 \mathrm{~mm}$.

\section{Diagnosis:}

Size, proportions, and other external characters similar to those of $P$. picea.

$\sigma^{*}$ : aedeagus $0.41-0.44 \mathrm{~mm}$ long; median lobe of distinctive morpholgy, with conspicuous shape of the apex. (Figs 44-46).

o: spermatheca minute and with strongly reduced duct (Fig. 47). 


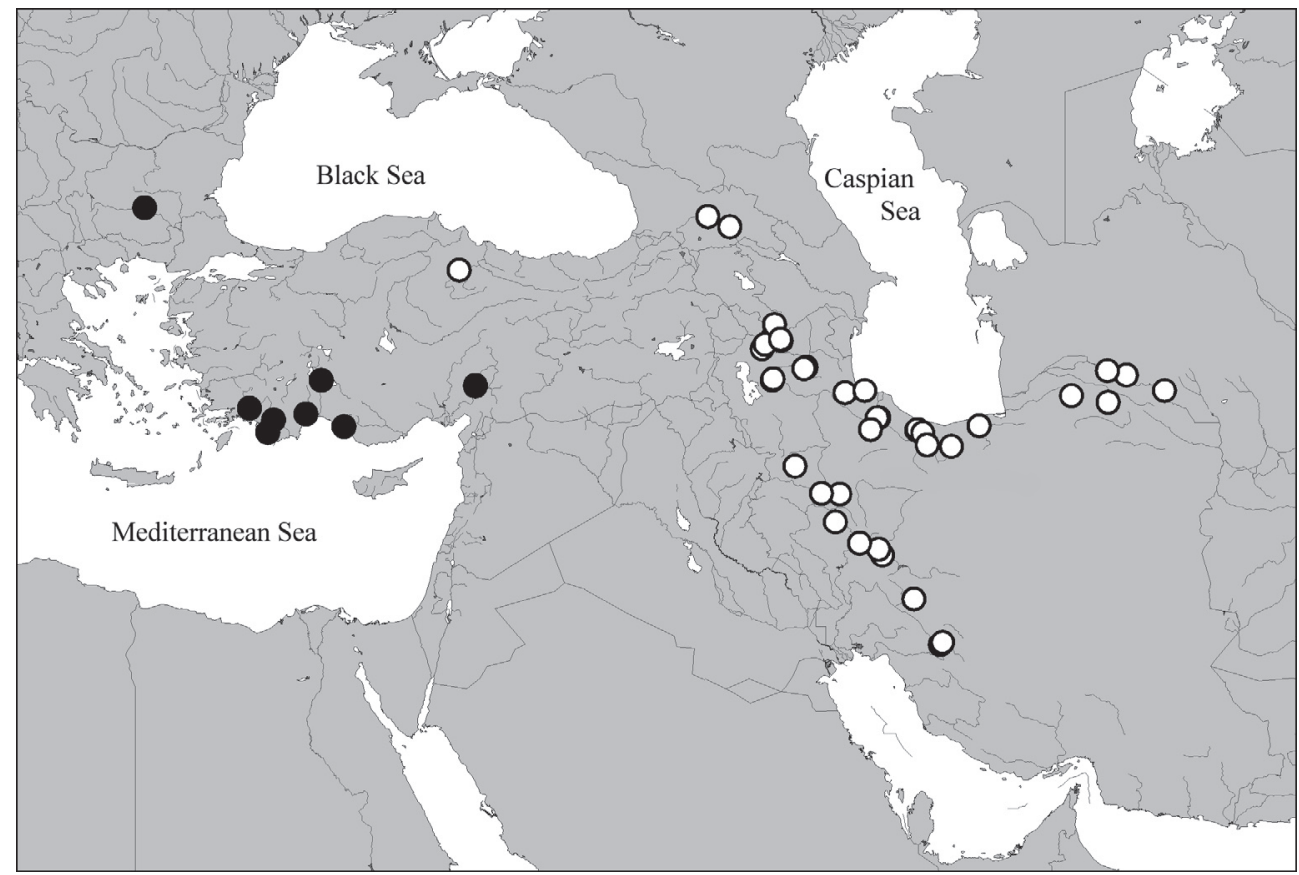

Map 4: Distributions of Pronomaea anatolica FAgel (filled circles) and P. khnzoriani Semenov (open circles), based on examined and literature records.

\section{Comparative notes:}

The aedeagus of $P$. anatolica is similar to that of its adelphotaxon $P$. khnzoriani, but distinguished especially by the shape of the apical internal structure. From other congeners, $P$. anatolica is at once separated by the distinctive shape of the median lobe of the aedeagus.

\section{Distribution and bionomics:}

The known distribution ranges from southeastern Bulgaria to central southern Anatolia (Map 4). The species has been collected in a variety of completely different habitats: in poplar litter at the coast, in leaf litter on the beach, in flood debris on a stream bank, at the margin of a mixed pine and cedar forest, in a damp forest clearing (with Juncus, etc.), and near snowfields at alpine elevations. The altitudes range from sea-level to $2225 \mathrm{~m}$. The specimens listed above were found in March, May, June, July, and October.

\section{Pronomaea khnzoriani Semenov, 2003 (Figs 48-50, Map 4)}

Pronomaea khnzoriani Semenov, 2003: 201.

\section{Comment:}

The original description of this recently described species is based on five type specimens from Armenia. The type material was not studied, but the detailed figures of the aedeagus in SEMENOV (2003) leave no doubt that the present interpretation is correct.

Additional material examined: Turkey: 2 exs., Amasya, 1888, leg. Korb (NHMW, cAss).

Georgia: 1 ex., Gori env., Uplichziche, 26.VI.1989, leg. Pütz (cWun); 10 exs., Tbilisi env., Tbilisskoye ozero ["Tbiliskoje osero"; $\left.41^{\circ} 44^{\prime} \mathrm{N}, 44^{\circ} 50^{\prime} \mathrm{E}\right]$, 19.VII.1985, leg. Wrase (DEI, cAss); 3 exs., W-Caucasus, 
"Landschaft Letschgum", leg. Leder (NHMW, cAss); 1 ex., "Swanetien", leg. Leder (NHMW).

Dagestan: 1 ex., locality not specified, leg. Leder \& Reitter (NHMW).

Turkmenistan: 3 exs., Kopet Dag, stream 6 km NE Tschuli near Firyuza, 18.IX.1975, leg. Hieke (cVog, cAss); 4 exs., W Ashkhabad, Sulyukly ["Transcaspia, Neu-Saratow", 3802N, 57²5E] (NHMW); 2 exs., Loțfābād ["Ljutfabad"] (NHMW).

Iran: 2 exs., Mazanderan, Sari, 36 34'N, 5309'E, 22.VII.1973, leg. Senglet (MHNG); 1 ex., Tehran, Tarazan-Lowshan, 36 $28^{\prime} \mathrm{N}, 49^{\circ} 31^{\prime} \mathrm{E}, 8 . \mathrm{VIII} .1974$, leg. Senglet (MHNG); 1 ex., Tehran, Agha Baba,

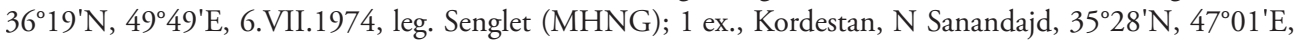
22.VI.1975, leg. Senglet (MHNG); 1 ex., Khorasan, NE Esfayaren, $37^{\circ} 12^{\prime} \mathrm{N}, 57^{\circ} 27^{\prime} \mathrm{E}, 1200 \mathrm{~m}, 29 . \mathrm{VII} .1975$,

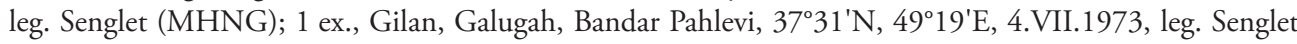
(MHNG).

\section{Diagnosis:}

Extremely similar to $P$. anatolica; distinguished only by the morphology of the aedeagus.

$\sigma^{*}$ : aedeagus of similar morphology as that of $P$. anatolica, but apical internal structure of different shape, in lateral view very thin (Figs 48-50).

ㅇ: spermatheca shaped like that of $P$. anatolica; for an illustration see figure 13 in SEMENov (2003).

\section{Comparative notes:}

From the highly similar $P$. anatolica - doubtlessly its sister species, as can be inferred from the similarly derived morphology of the male primary sexual characters -, this species is reliably separated only by the shape of the apical internal structure of the aedeagus. From all other congeners it is at once distinguished also by the conspicuous shape of the median lobe of the aedeagus, and from all the species, except $P$. anatolica, $P$. flavirostris, and $P$. procerula, also by the shape of the spermatheca.

\section{Distribution and bionomics:}

Pronomaea khnzoriani was previously known from Armenia, Georgia, and Iran (Assing in press). It is here recorded from Turkey, Dagestan, and Turkmenistan for the first time (Map 4). In Iran, the species is rather common on the banks of rivers and streams; for numerous additional records see Assing (in press). The altitudes specified on the labes range from 400 to $2710 \mathrm{~m}$. The species has been collected in April (SEmenov 2003) and in large numbers during the period from June through August (Assing in press; material examined). Three specimens were taken in September. Some beetles collected in June are teneral.

\section{Pronomaea flavirostris Semenov, 2003 (Fig. 51, Map 5)}

Pronomaea flavirostris Semenov, 2003: $201 \mathrm{f}$.

\section{Comment:}

The original description is based on three type specimens from "Rayon Moskowskij" near Kuljab, Tajikistan. The type material was not examined, but the detailed illustration of the aedeagus provided by Semenov (2003) leaves no doubt that it is conspecific with the material listed below.

\section{Material examined:}

Tajikistan: 1 ex., Kuliab, Aksu valley, 1898, leg. Hauser (FMNH); 1 ex., Hissar mts., 1898, leg. Hauser (cAss); 4 exs., Dushanbe, Romit valley, 18.VII.1984, leg. Wrase (cVog, cAss); 7 exs., 
Seravshan mts., S Panjakent, Rudaky, 1500 m, 11.VII.1990, leg. Schülke \& Wrase (DEI, cSch, cAss); 3 exs., Pamir Alai, Hissar mts., N Dushanbe, Adshuk cleft near Varzob, 1200 m, 1.-3. VII.1990, leg. Schülke \& Wrase (DEI, cAss); 9 exs. [partly teneral], Pamir Alai, Dushanbe, Rommit valley, 2000 m, 18.VII.1984, leg. Behne (DEI, cAss); 3 exs., Hissar mts., 1898, leg. Hauser (NHMW, cAss); 1 ex., Karateghin mts., Saripul ["Sary-Pul", 38²5'N, 7008'E], 1482 m, 1898, leg. Hauser (NHMW); 1 ex., Gorno Badakhshanskiy Autonomous Oblast, Rushanskiy mts., near geologists' camp, 2200 m, 21.V.1982, leg. Mikhailov (cSch).

Afghanistan: 1 ex., Tangui Gharou ["Tang-Gharou"; 34³3'N, 69³0'E], 6.VIII.1959, leg. Lindberg (NHMW); 1 ex., Qadès, "Grotte", 1350 m, 30.VI.1959, leg. Lindberg (cAss).

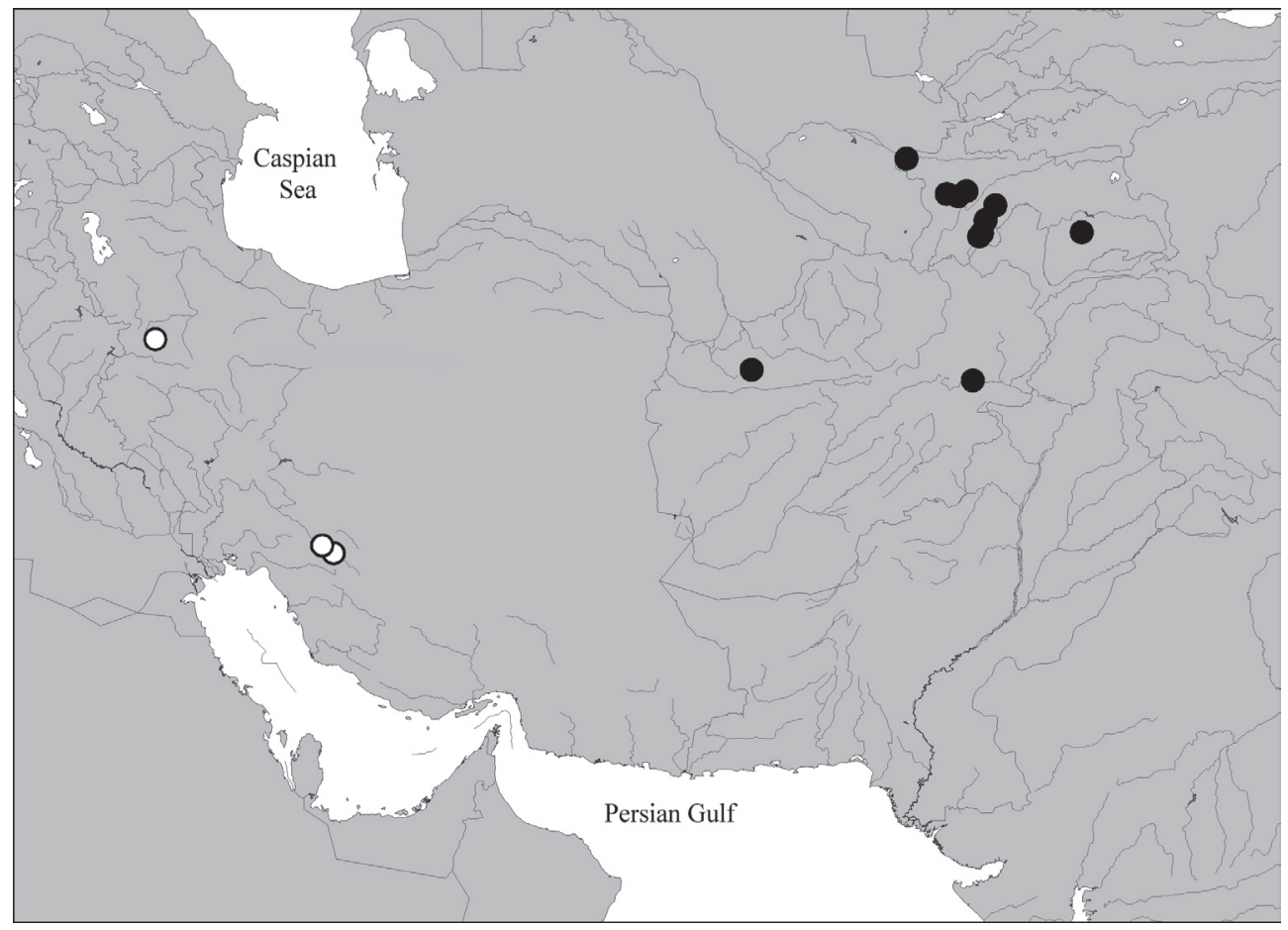

Map 5: Distributions of Pronomaea flavirostris Semenov (filled circles) and P. procerula Assing (open circles), based on examined and literature records.

\section{Diagnosis:}

External characters similar to that of $P$. picea, except for the slightly less convex pronotum (crosssection). Reliably identified only based on the sexual characters.

$\sigma^{*}$ : aedeagus larger (0.45-0.48 mm long); median lobe at base of ventral process without projection and not bulging (Fig. 51).

P: spermatheca of similar shape as that of $P$. anatolica and P. khnzoriani; for an illustration see figure 16 in Semenov (2003).

\section{Comparative notes:}

The species is reliably separated from other Western Palaearctic and Middle Asian congeners only based on the morphology of the aedeagus. 


\section{Distribution and bionomics:}

The species was previously known only from Tajikistan (SEmenov 2003). It is here reported from Afghanistan for the first time (Map 5). The species has been collected at altitudes of up to $2200 \mathrm{~m}$ during the period from May through August; teneral adults were observed in July. According to SEmenov (2003), the type specimens were collected on a stream bank.

\section{Pronomaea procerula Assing, in press (Map 5)}

Additional material examined: Iran: 2 exs., Kordestan, N Sanandajd, $35^{\circ} 28^{\prime} \mathrm{N}, 47^{\circ} 01^{\prime} \mathrm{E}, 22 . V I .1975$, leg. Senglet (MHNG, cAss).

\section{Diagnosis:}

Highly distinctive species; for a detailed description see Assing (in press).

Body slender. Antennae and legs conspicuously long and slender, preapical antennomeres not transverse. Pronotum of distinctive shape, almost cordiform: maximal width in anterior half, strongly tapering posteriad; width of posterior margin $0.75-0.80$ times maximal pronotal width; lateral margins smoothly sinuate in posterior half. Elytra only with moderately dense puncturation. For illustrations of the habitus, the forebody, and the antenna see figures 23-25 in Assing (in press).

$\sigma^{\text {t }}$ : aedeagus $0.45-0.47 \mathrm{~mm}$ long); shape of median lobe somewhat resembling that of $P$. flavirostris, but more slender, ventral process more strongly bent (in relation to base), and internal sac with remarkably long flagellum; for illustrations see figures 27-30 in Assing (in press).

+ : spermatheca of similar shape as that of $P$. anatolica and $P$. khnzoriani; for an illustration see figure 34 in Assing (in press).

\section{Comparative notes:}

The species is readily distinguished from all other representatives of the genus distributed in the Western Palaearctic region and Middle Asia by the distinctly longer and more slender antennae and legs, the conspicuous shape of the pronotum (cordiform shape, sinuate lateral margins), the sparser puncturation of the pronotum and the elytra, as well as by the morphology of the aedeagus, especially the remarkably long flagellum.

\section{Distribution and bionomics:}

The known distribution is confined to western Iran (Map 5); for additional localities see Assing (in press). It is here reported from Afghanistan for the first time. The species has been collected on river banks at altitudes of 1940 and 2040 m (Assing in press) in June and July.

\section{Key to the Pronomaea species of the Western Palaearctic region, including Middle} Asia

1. Antennae and legs conspicuously long and slender; antennomere $\mathrm{X}$ not transverse. Pronotum cordiform, distinctly narrowed posteriad; width at posterior margin 0.75-0.80 times maximal pronotal width; lateral margins smoothly sinuate in posterior half (dorsal view), posterior angles pronounced. Elytral puncturation less dense. $\sigma^{-1}$ : median lobe of aedeagus shaped as in figures 23-25 in Assing (in press), with very long flagellum. ㅇ: spermatheca minute and with very short duct (figure 34 in Assing (in press)). Iran (Map 5). 
Antennae and legs shorter; antennomere $\mathrm{X}$ transverse, usually approximatey 1.5 times as wide as long. Pronotum weakly tapering posteriad; width at posterior margin usually approximately 0.90-0.95 times maximal pronotal width; lateral margin not or only indistinctly sinuate in posterior half; posterior angles obtuse. Elytral puncturation denser. $\sigma^{\star}$ : aedeagus of different shape and with shorter flagellum.

2. Eyes less prominent and smaller, shorter than postocular region in dorsal view (Fig. 35). Coloration of body on average paler, head and pronotum rufous to brown. $\sigma^{-1}$ : aedeagus without projection at base of ventral process (lateral view).

Eyes more prominent and larger, at least as long as postocular region in dorsal view. Coloration of body on average darker; head and pronotum usually dark brown to blackish. ... 4

3. $\sigma^{7}$ : median lobe of aedeagus at base of ventral process (i. e. near crista apicalis) not bulging; apex of ventral process obliquely truncate; flagellum shorter, darker, and stouter (Figs 36-39). Widespread from Caucasus region to Cyprus, Lebanon, and Iran (Map 3).

P. araxicola REITTER

$\sigma^{*}$ : median lobe of aedeagus at base of ventral process (i. e. near crista apicalis) somewhat bulging; apex of ventral process rounded; flagellum longer and more slender (Figs 41-42). Israel. (Map 3)

P. spalacis sp. n.

4. $0^{\top}$ : median lobe of aedeagus at base of ventral process (near crista apicalis) without projection or transverse carina (best seen in lateral view). 9 : spermatheca shaped as in Fig. 47, minute and with extremely short duct. Eastern Mediterranean, Caucasus region, Middle Asia. 5

$\sigma^{\top}$ : median lobe of aedeagus at base of ventral process (near crista apicalis) with more or less pronounced projection or carinae. $q$ : spermatheca less minute; duct distinctly longer than capsule. 7

5. $\sigma^{t}$ : median lobe of aedeagus shaped as in Fig. 51, ventral process almost straight in lateral view. Tajikistan, Afghanistan (Map 5). P. flavirostris SEMENOV $\sigma^{\star}$ : ventral process of aedeagus strongly sinuate in lateral view. Distribution different. .....

6. $0^{t}$ : apical internal structure of aedeagus very slender and evenly bent (Figs 48-50). Caucasus region to northern Turkey, Armenia, Iran, and Turkmenistan (Map 4).

P. khnzoriani SEMENOV

$\sigma^{*}$ : apical internal structure of aedeagus of different shape (Figs 44-51). SE-Bulgaria, SWand S-Anatolia (Map 4). P. anatolica FAGEL

7. Pronotum larger in relation to head, usually at least 1.3 times as wide as head; pronotal pubescence shorter and usually more or less depressed. Antennae usually uniformly blackish, with the basal antennomeres at most only slightly paler than apical antennomeres. $\sigma^{*}$ : median lobe of aedeagus shaped as in Figs 1-7. o : spermatheca with longer duct (Fig. 8). Distribution Atlanto-Mediterranean, from NW-Africa and the Iberian Peninsula to Belarus (Map 1). P. rostrata ERICHSON

Pronotum smaller in relation to head, usually at most 1.3 times as wide as head; pronotal pubescence longer and usually suberect. Basal antennomeres often of paler coloration than apical antennomeres. $\sigma^{t}$ : median lobe of aedeagus of different shape. 9 : spermatheca with shorter duct. 
8. $0^{\pi}$ : median lobe of aedeagus at base of ventral process with fine carina very close to crista apicalis (Figs 26-28). Crete (Map 2).

P. wunderlei sp. $\mathrm{n}$.

$\sigma^{*}:$ median lobe of aedeagus at base of ventral process with more prominent projection in different position. Distribution different. 9

9. $0^{*}$ : median lobe of aedeagus at base of ventral process with less pronounced and distinctly angular projection (Figs 30-34). Species from Sardinia and Sicily. 10

$\sigma^{\star}$ : median lobe of aedeagus at base of ventral process with more massive and usually not distinctly angular projection. Distribution different. 11

10. $\sigma^{\top}$ : median lobe of aedeagus smaller, approximately $0.38 \mathrm{~mm}$ long; flagellum shorter; angular projection at base of ventral process more prominent (Figs 32-34). Sardinia (Map 1).

P. sardoa sp. n.

$\sigma^{*}$ : median lobe of aedeagus larger, approximately $0.42 \mathrm{~mm}$ long; flagellum longer; angular projection at base of ventral process less prominent (Figs 29-31). Sicily (Map 1).

\section{P. sicula sp. $\mathrm{n}$}

11. Antenna usually of uniformly blackish coloration, basal antennomeres at most only slightly paler than apical antennomeres. $\sigma^{\star}$ : projection at base of ventral process of aedeagus rounded to nearly angular; apex of ventral process more slender in lateral view (Figs 18-24). Corsica (Map 2). P. corsicana sp. $\mathrm{n}$.

Basal antennomeres usually somewhat paler than remainder of antenna, yellowish brown to brown. $\sigma^{*}$ : projection at base of ventral process more or less truncate apically; apex of ventral process less slender (Figs 9-15). Widespread Ponto-Mediterranean species, distributed from the Balkans to western France (Map 2).

P. picea HeER

Catalogue of the Pronomaea species of the Palaearctic region

\begin{tabular}{|l|l|}
\hline Species & Distribution \\
\hline anatolica FAGEL, 1969 & Bulgaria, SW-and S-Turkey \\
\hline $\begin{array}{l}\text { araxicola ReITTER, 1898 } \\
=\text { subterranea IABLOKOFF-KHNZORIAN, } 1957 \\
=\text { libanotica FAGEL, 1969; syn. n. } \\
=\text { orientalis FAGEL, 1969; syn. n. }\end{array}$ & $\begin{array}{l}\text { Azerbaijan, Armenia, Georgia, Russian South European } \\
\text { territory, Turkey, Cyprus, Lebanon, Iran }\end{array}$ \\
\hline corsicana sp. n. & France: Corsica \\
\hline flavirostris SEMENOv, 2003 & Tajikistan, Afghanistan \\
\hline khnzoriani SEMENOv, 2003 & Armenia, Georgia, Dagestan, N-Turkey, Iran, Turkmenistan \\
\hline nepalensis PACE, 1989 & Nepal \\
\hline $\begin{array}{l}\text { picea HeER, 1841 } \\
=\text { dalmatina SACHSE, 1852; syn. n. } \\
=\text { korgei LOHSE, 1974; syn. n. }\end{array}$ & $\begin{array}{l}\text { Balkans, Central Europe, Italy (mainland), France, Ukraine, } \\
\text { ?Belgium }\end{array}$ \\
\hline procerula AsSING, in press & Iran \\
\hline $\begin{array}{l}\text { rostrata ERICHSON, 1837 } \\
=\text { horioni LOHSE, 1968 }\end{array}$ & $\begin{array}{l}\text { N-Africa: Tunisia, ?Algeria, ?Morocco; Iberian Peninsula: } \\
\text { Spain, Portugal, Gibraltar; France, Central Europe, Italy, } \\
\text { Ukraine, ?Belarus }\end{array}$ \\
\hline sardoa sp. n. & Italy: Sardinia \\
\hline
\end{tabular}




\begin{tabular}{|l|l|}
\hline Species & Distribution \\
\hline sicula sp. $\mathrm{n}$. & Italy: Sicilia \\
\hline spalacis sp. $\mathrm{n}$. & Israel \\
\hline taiwanensis PACE, 2007 & Taiwan \\
\hline $\begin{array}{l}\text { thaxteri BERNHAUER, 1915 } \\
=\text { leontopolitana CAMERON, 1919 }\end{array}$ & $\begin{array}{l}\text { China; Oriental region: Myanmar, Malaysia, Singapur, } \\
\text { Philippines, Thailand, Borneo, Sumatra, Java }\end{array}$ \\
\hline wunderlei sp. $\mathrm{n}$. & Greece: Crete \\
\hline
\end{tabular}

\section{Acknowledgements}

My sincere thanks are extended to all the colleagues listed in the material section for the loan of material under their care. In particular, I am grateful to Paul Wunderle for the generous gift of the holotypes of two species. Marc Tronquet supplied the habitus photograph of $P$. corsicana. Michael Schülke, Marc Tronquet, and Lothar Zerche helped with the identification of various localities. Benedikt Feldmann (Münster) proofread the manuscript.

\section{References}

Assing, V. in press: New species and additional records of Paederinae and Aleocharinae from Iran (Coleoptera, Staphylinidae). - Deutsche Entomologische Zeitschrift 54 (2) (2007).

Cameron, M. 1936: Fauna Sumatrensis Bijdrage No. 77, Staphylinidae (Coleoptera). - Tijdschrift voor Entomologie 79: 1-24.

Bernhauer, M. \& Scheerpeltz, O. 1926: Staphylinidae VI. Pars 82). - In: Junk, W. \& Schenkling, S. (eds.): Coleopterorum Catalogus. Volumen 5. Staphylindae. - Berlin, W. Junk: 499-988.

Coiffart, H. 1976: Staphylinidae récoltés par M. Cerruti dans la région mediterranéenne orientale (Coleoptera). - Fragmenta Entomologica 12: 81-101.

Erichson, W. F. 1837: Die Käfer der Mark Brandenburg. Erster Band, Erste Abtheilung. - Berlin, F. H. Morin: viii + 384 pp.

FAGEL, G. 1969: Contribution à la connaissance des Staphylinidae CVII. Sur les «Pronomaea» de la Région paléarctique occidentale. - Bulletin et Annales de la Société Royale d'Entomologie de Belgique 105: 27-32.

Franz, H. 1938: Aus der Praxis des Käfersammlers. XXXIII. Eine Käferfauna aus Fuchsbauen des nördlichen Burgenlandes. - Koleopterologische Rundschau 24: 30-32.

Fauvel, A. 1902: Catalogue des Staphylinides de la Barbarie de la Basse-Égypte et des Iles Açores, Madères, Salvages et Canaries. - Revue d'Entomologie 21: 45-189.

Ganglbauer, L. 1904: Verzeichnis der auf der dalmatinischen Insel Meleda vorkommenden Koleopteren nach den Sammelergebnissen des Herrn Forstrates Alois Gobanz. - Verhandlungen der zoologischbotanischen Gesellschaft Wien 54: 645-550.

Heer, O. 1841: Fascicule III [pp. 361-652]. - In: Fauna Coleopterorum Helvetica Pars I. - Turici, Orelii, Fuesslini et Sociorum: xii +652 pp.

Horion, A. 1967: Faunistik der mitteleuropäischen Käfer. Bd. XI: Staphylinidae, 3. Teil: Habrocerinae bis Aleocharinae (ohne Subtribus Athetae). - Überlingen-Bodensee: 419 pp.

Horn, W.; Kahle, I.; Friese, G. \& Gaedike, R. (1990): Collectiones entomologicae. Ein Kompendium über den Verbleib entomologischer Sammlungen der Welt bis 1960. - Akademie der Landwirtschaftswissenschaften der Deutschen Demokratischen Republik, Berlin: 573 pp.

ICZN 1999: International Code of Zoological Nomenclature. Fourth Edition. - London: xxix + 306 pp.

IAblokoff-Khnzorian, S. M. 1957: Dva novykh zhuka-stafilina na Armyanskoi SSR (Coleoptera, Staphylinidae). - Zoologicheskiy Zhurnal 36: 291-293. 
Korge, H. 1964: Carabiden- und Staphylinidenfunde in den Pontischen Gebirgen Kleinasiens und in Mazedonien (Coleoptera). - Reichenbachia 4 (14): 105-126.

Lohse, G. A. 1968: Eine neue Art der Gattung Pronomaea Er. (Coleoptera, Staphylinidae). - Nachrichtenblatt der Bayerischen Entomologen 17: 41-42.

Lohse, G. A. 1974: Tribus 1-13: Deinopsini-Falagriini [pp. 11-72]. - In: Freude, H.; Harde, K. W. \& Lohse, G. A. (eds.): Die Käfer Mitteleuropas. Band 5. Staphylinidae II (Hypocyphtinae und Aleocharinae), Pselaphidae. - Krefeld, Goecke \& Evers: 381 pp.

Luze, G. 1904: Beitrag zur Staphyliniden-Fauna von Russisch-Centralasien (Coleoptera). - Horae Societatis Entomologicae Rossicae 37: 74-115.

Newton, A. F.; Thayer, M. K.; Ashe, J. S. \& Chandler D. S. 2001: Superfamily Staphylinoidea Latreille, 1802, Staphyliniformia Lameere, 1900; Brachelytra auctorum. 22. Staphylinidae Latreille, 1802. - In: Arnett, R. H. JR. \& Thomas, M. C.: American Beetles. Archostemata, Myxophaga, Adephaga, Polyphaga: Staphyliniformia. Volume 1, CRC Press, Boca Raton etc.: 272-418.

PaCe, R. 1989: Aleocharinae nepalesi del Museo di Ginevra. Parte I (Coleoptera, Staphylinidae). - Revue Suisse de Zoologie 96: 483-539.

PACE, R. 1994: Aleocharinae della della sottoregione africana orientale al Museo di Ginevra (Coleoptera, Staphylinidae) Parte I. - Revue Suisse de Zoologie 100: 117-193.

PACE, R. 1998: Aleocharinae della Cina: Parte I (Coleoptera, Staphylinidae). - Revue Suisse de Zoologie 105: 139-220.

PACE, R. 2007: Specie nuove o poco note dei generi Leucocraspedum Kratz, Myllaena Er. e Pronomaea Er. di Taiwan (Coleoptera, Staphylinidae). - Bollettino del Museo Civico di Storia Naturale di Verona 31: 131-139.

Reitter, E. 1898: Siebzehnter Beitrag zur Coleopteren-Fauna des russischen Reiches. - Wiener Entomologische Zeitung 17: 109-127.

SACHSE, C. T. 1852: Neue Käfer. - Entomologische Zeitung (Stettin) 13: 115-127.

ScheErpeltz, O. 1937: Wissenschaftliche Ergebnisse einer von Herrn Hofrat F. Schubert, seinem Sohne Herrn cand. Phil. F. Schubert und Herrn Prof. Ing. K. Mandl im Sommer 1935 (1936) nach Bulgarien unternommenen Studienreise. Coleoptera: I. Staphylinidae. - Mitteilungen aus den Königlichen Naturwissenschaftlichen Instituten 10: 185-246.

Scheerpeltz, O. 1964: Staphyliniden von der Insel Kreta (Coleoptera). - Annales Historico-Naturales Musei Nationalis Hungarici (Zoologica) 56: 297-308.

ScheErpeltz, O. 1965: Die im westlichen, zentralen und südlichen Sizilien und in den "Monti Iblei“ aufgefundenen Staphyliniden-Gattungen und Arten. - Bollettino delle sedute dell'Accademia Gioenia di Scienze naturali in Catania, Serie 4, 8: 496-517.

Semenov, V. B. 2003: Die kaukasischen und mittelasiatischen Arten der Gattung Pronomaea Erichson, 1837 (Coleoptera: Staphylinidae: Aleocharinae). - Russian Entomological Journal 12: 199-202.

Smetana, A. 2004: Staphylinidae, subfamily Aleocharinae, pp. 353-494. - In: Löbl, I. \& SmetanA, A. (eds): Catalogue of Palaearctic Coleoptera. II. Hydrophiloidea - Histeroidea - Staphylinoidea. - Stenstrup, Apollo Books: 942 pp.

Author's address:

Dr. Volker Assing

Gabelsbergerstr. 2

30163 Hannover

Germany

e-mail: vassing.hann@t-online.de

\section{Subject editor:}

Dr. L. Zerche 